\title{
الممارسات الطبية في مصر
}

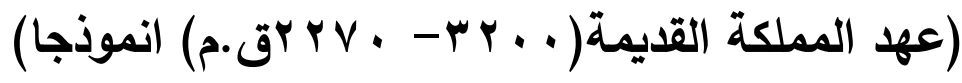

أ.د. مهاية فيصل صالح الموسوي

جامعة بغداد - كلية التربية للعلوم الانسانية -ابن رشد/قسم التاريخ

\section{dr.historym.faisal@gmail.com}

(مُلَخََّصُ البَحثث)

لا يختلـف اثتـان علـى ان الطـب مـن أول المعـارف التـي مارسـها الانســان مـن

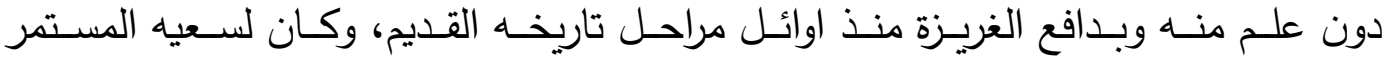

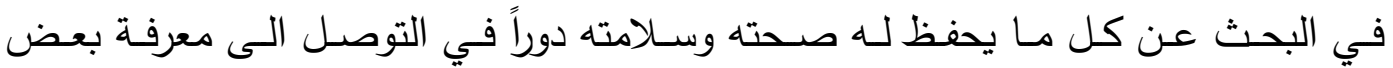

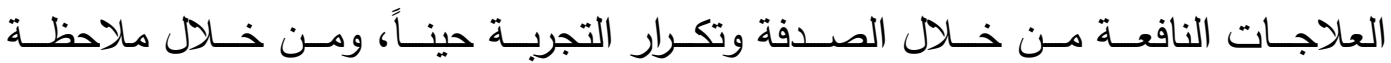

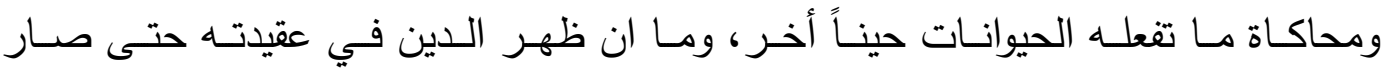

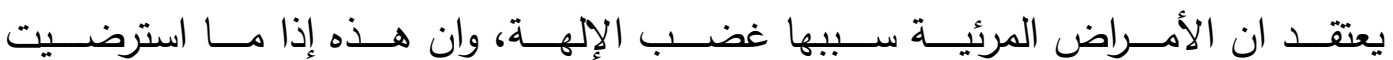

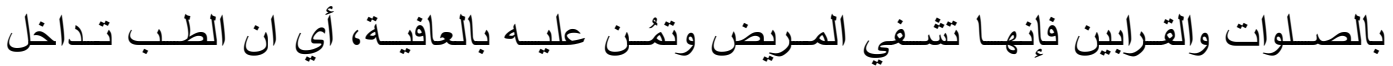

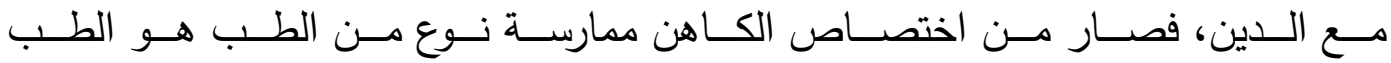

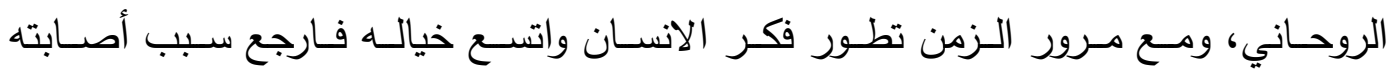

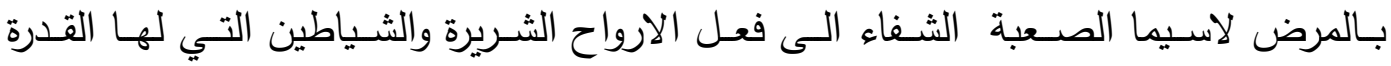

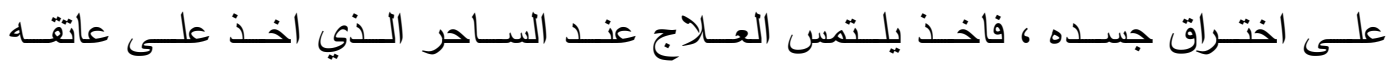
ممارسـة الطب مـن خـلال القيام بنوع مـن الحيل وقراءة بعض العـزائم والتعاويـذ وحمـل

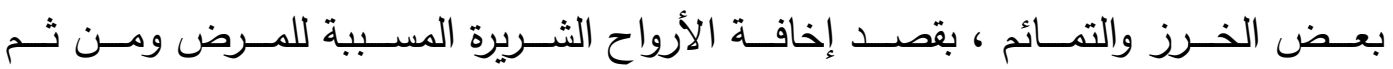

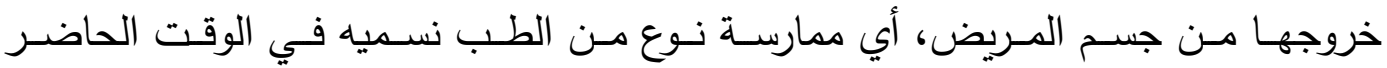
الطب الوقائي.

الا انـهـ وعلـى الـرغم مـن هـذا الخـــ الواضـح بـين الطـب والـدين والسـحر فـان

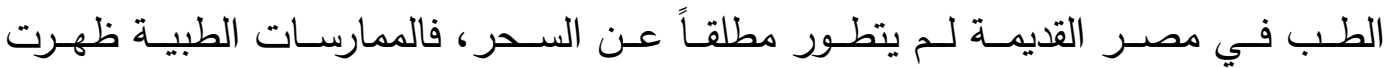

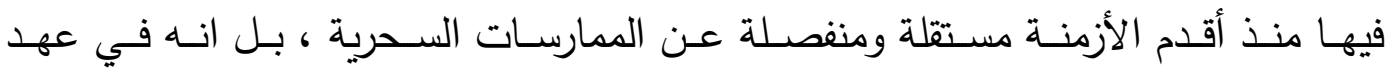

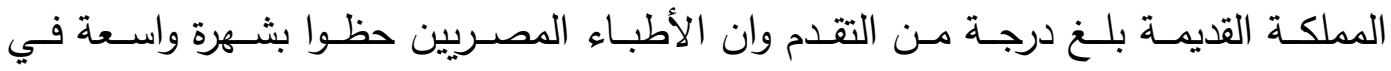
الخارج ، وانَّ أطباء الاغريق كانوا من تلاميذ الددرسة الطبية الدصرية. الكلمات المفتاحية: الطب ، المرض ، العلاج ، البرديات الطبية . 


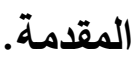

ان اقدم مـا وصـلنا مـن معلومـات عـن الطب في حضــارات العـالم القديم بعد بـلاد

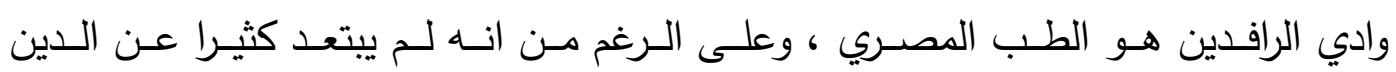

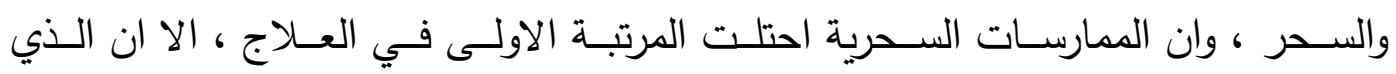

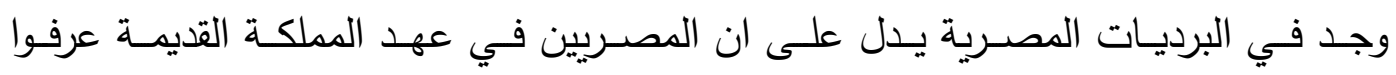

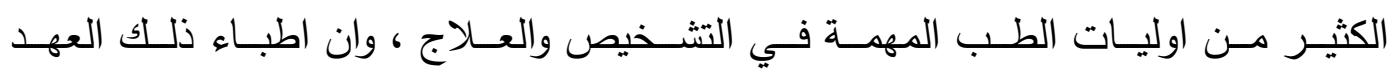

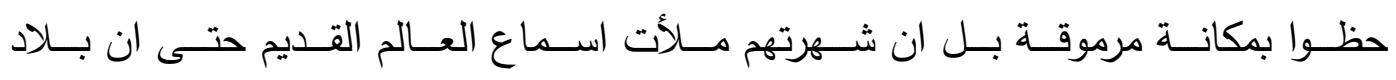

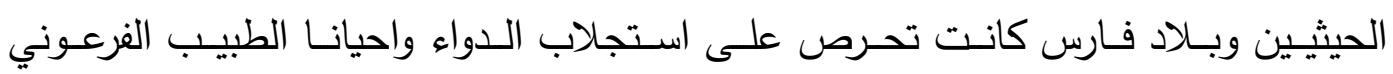

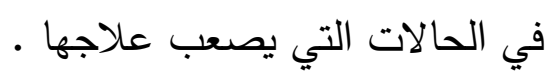

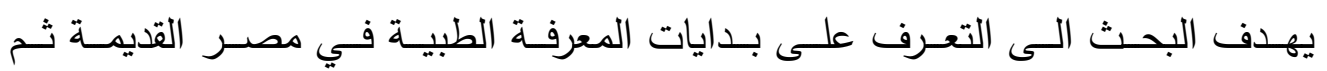

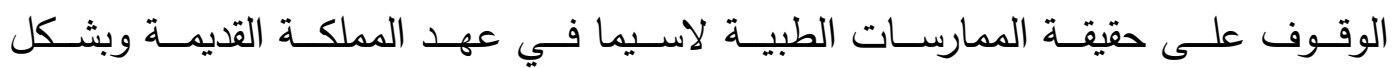

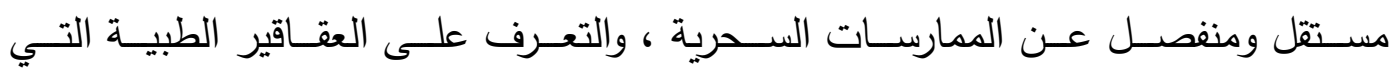

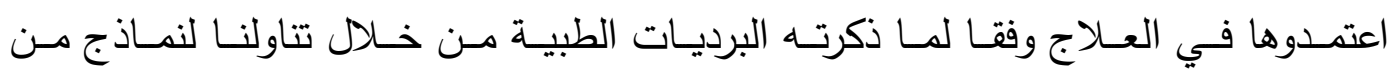

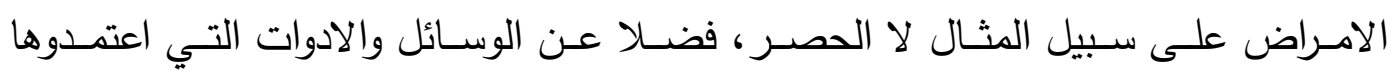
في معالجتهم للجروح والكسور التي يصابون بها اثناء العمل او القتال. اولاًَ- بواكير الطب في مصر القديمة.

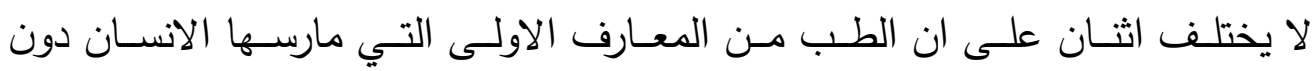

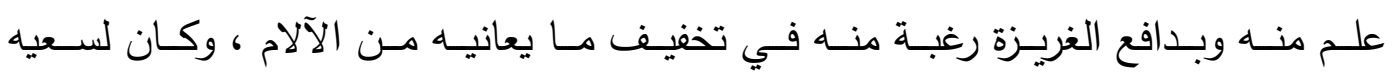

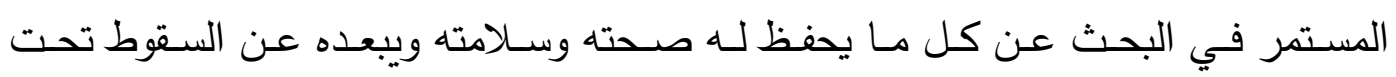

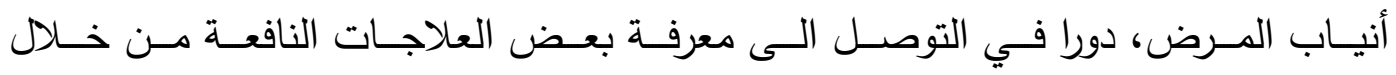

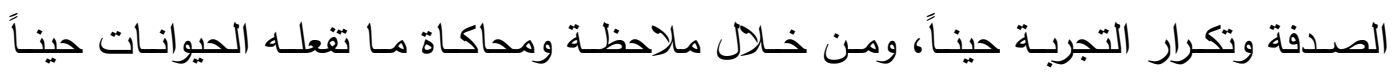

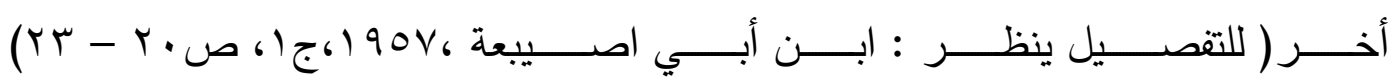
For details see: Ibn Abi Usaib’a,1957,Vol.1,p.p.20-22)

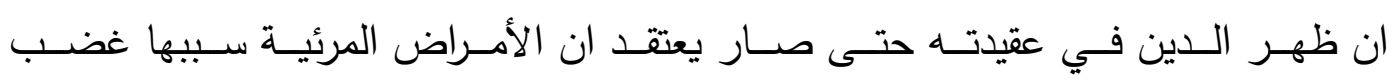

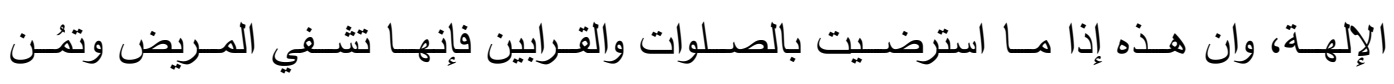

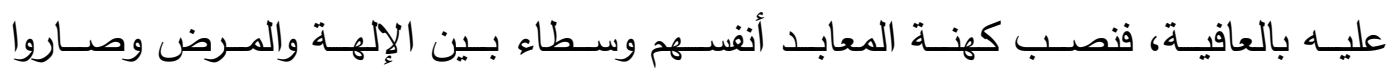

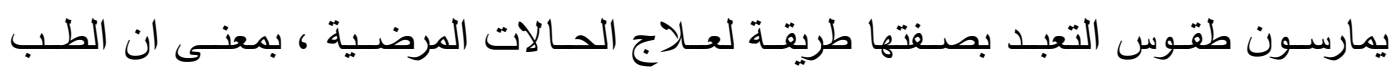

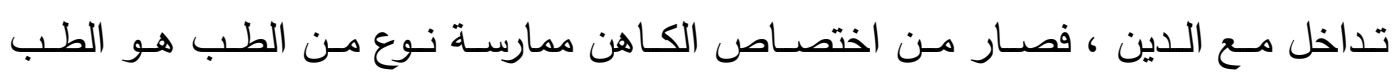

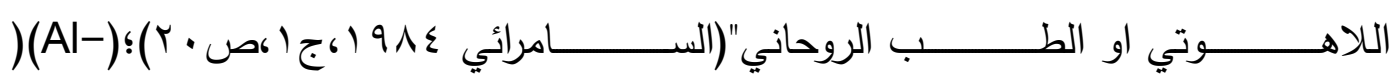
(Murad,N.D,p.31) (مراد،د.ت ،ص آبSSamera'l,1984,Vol.1,p.20 


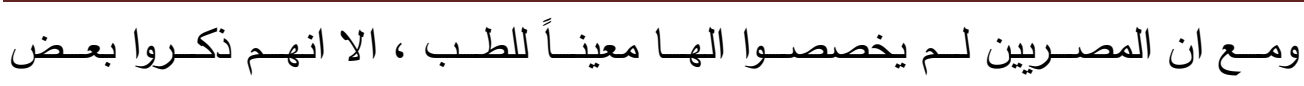

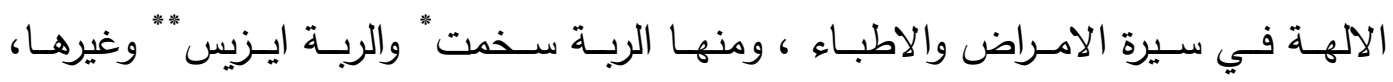

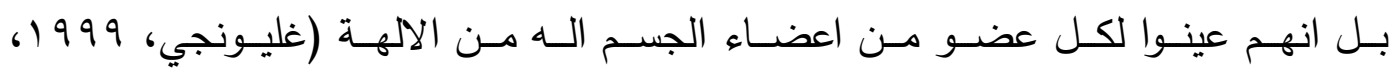

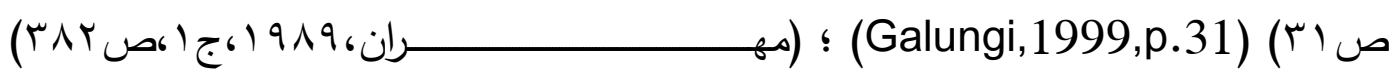

.( Mahran, 1989,Vol.1,p.382)

ومــع مـرور الـزمن تطــور فكـر الانســان واتسـع خيالــه فـارجع سـبـ أصــابته

بـالمرض لاسـيما الصـعبة الثـفاء الـى فعـل الارواح الثـريرة والثـياطين التـي لهـا القـدرة على اختـراق جسـده، فاخـ يلتمس العـلاج عنــ السـاحر الذي اخذ على عاتقـه ممارسـة

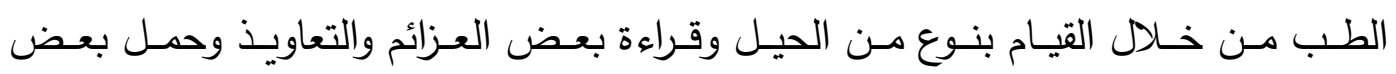

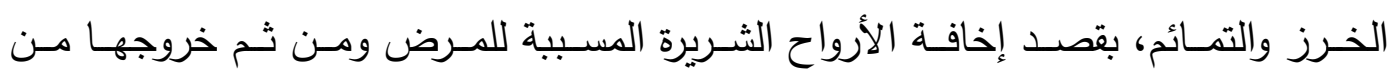

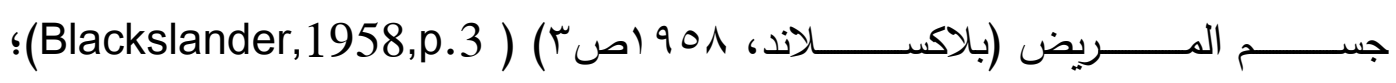

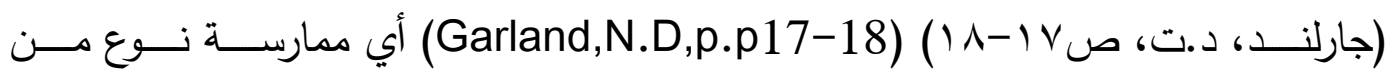
الطب نسميه في الوقت الحاضر الطب الوقائي. نخلـص مـن ذلــك ان الطـب فـي اول امــره كـان متصــلاً بالـدين ومتماشـياً مــع السـحر ومعظـم الاطبــاء كـانوا مـن الكهنـة المطهـرين (وعـب uab) ومـنهم مسن كـانوا مشـرفين على كهنـة وعـب ، والطبيـب في الغالب كـان يمـارس اعمالـه الطبيـة بجانـب

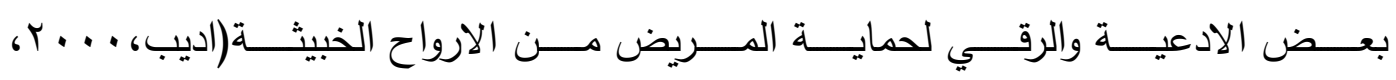
صن (Adeeb,2000,p.576)(ov7)

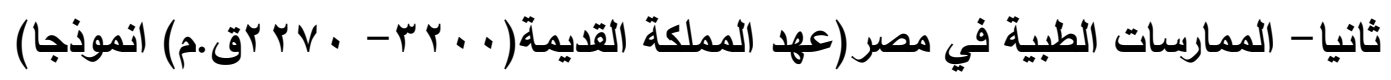
على الرغم من هذا الخلط الواضـح بين الطب والدين والسحر الا إن الطب في مصر

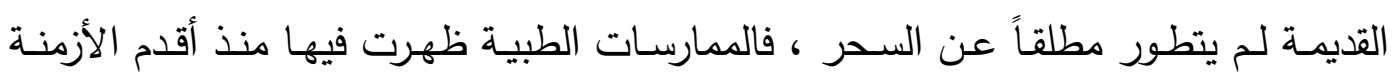
مستقلة ومنفصلة عن الممارسات السحرية ،فاستعمال الملكيت الاخضر (كربونات النحاس

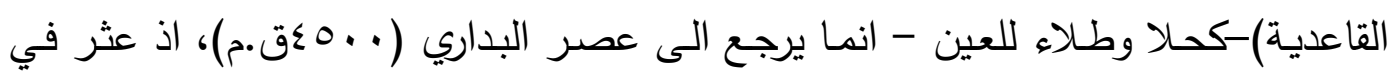
مقابر ذللك العصر على الكثير من الصحون والادوات التي كانت تستعمل في طحن وسحق تلك المـادة (الدريد، بـ ـ ب،صسمه) (Aldred,2013,p.53)، وان استعمال الجاليــا (خـام

* سخمت : يعني اسمها الاكثر قوة ، عرفت بطبيعتها الازدو اجية فهي المسؤولة عن نشر الامر اض والاوبئة

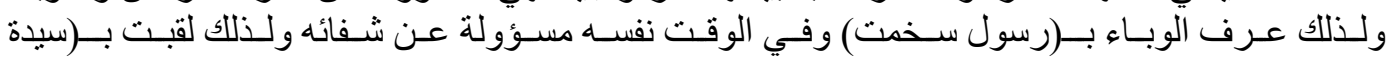

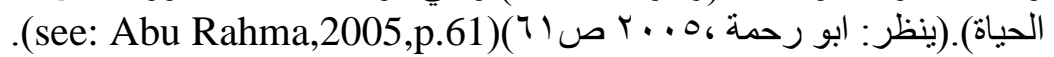

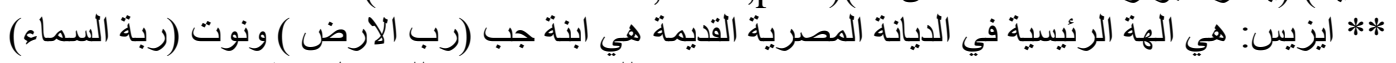

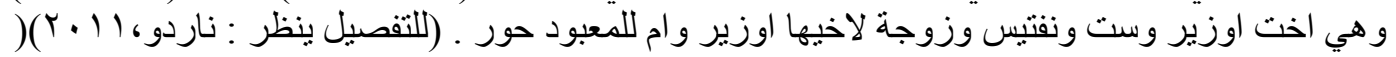
.(For details see: Nardo,2011 
الرصاص) لأغراض مشابهة جاء بعد ذلك في عصور ما قبل الاسرات ، امـا الختان فكان

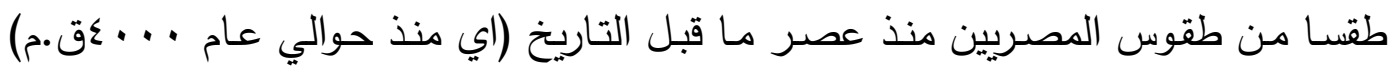

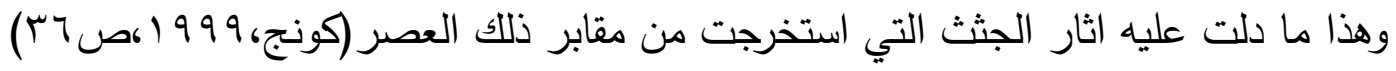

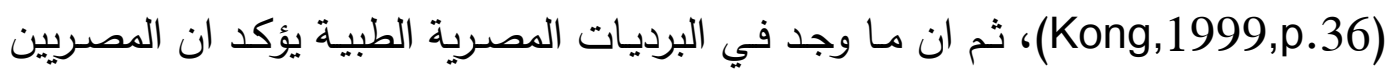

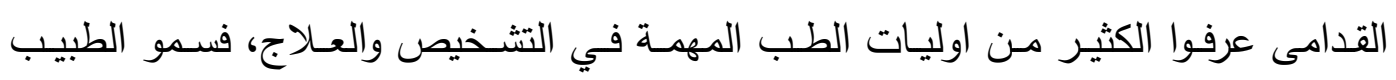

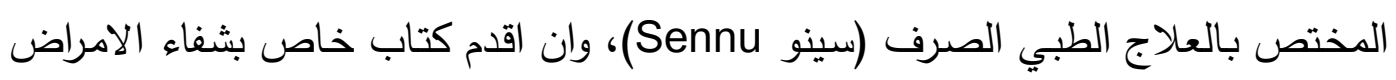

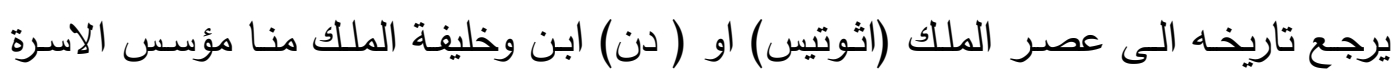

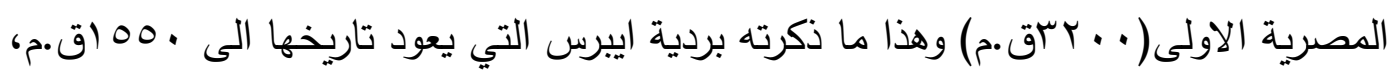

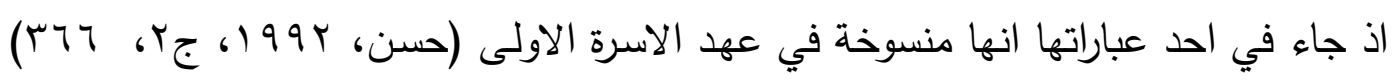

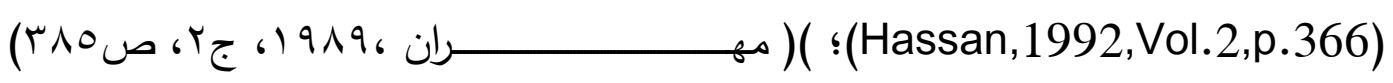
(Mahran,1989,Vol.1,p385)

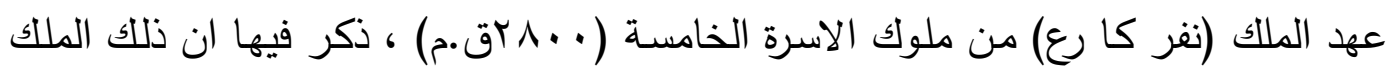

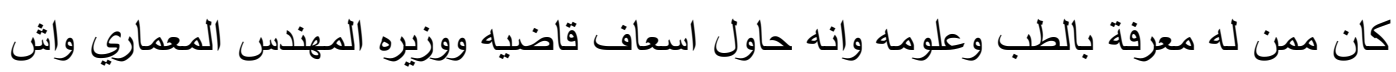
- بتاح (Ueshptah) الذي سقط مغشيا عليه، وبعد ان امر الملك بنقله الى جناح قصره

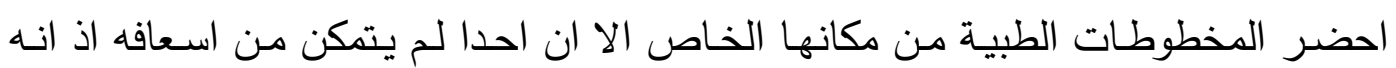

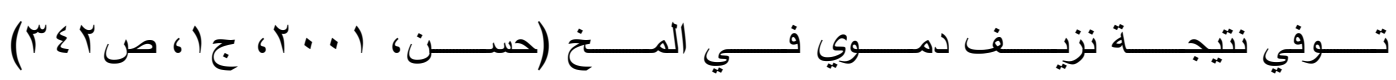

(Dalio,2013,p.63) (د) (Hassan,2001,Vol.1,p.342)

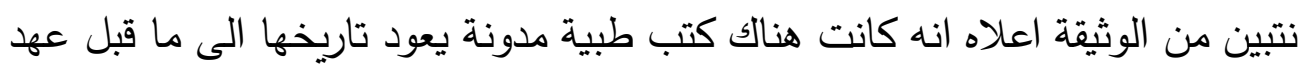

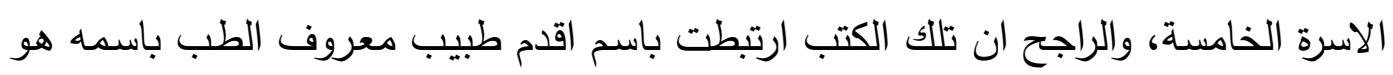

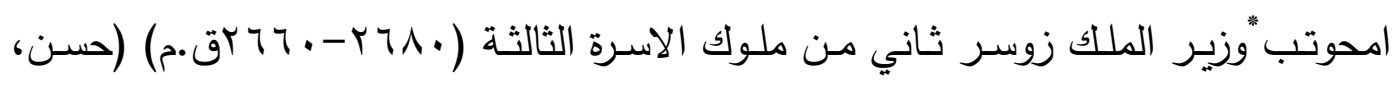

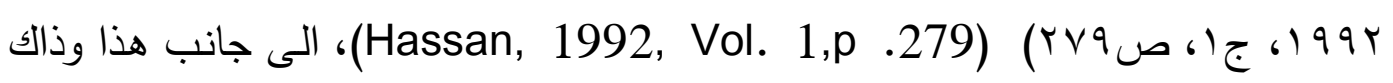

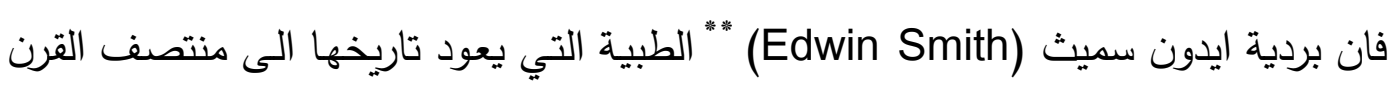

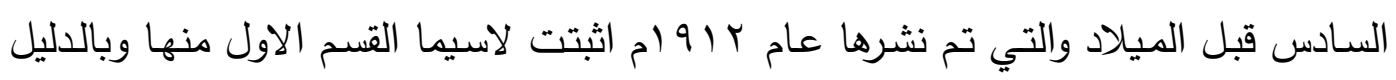
القاطع ان الطب المصري القديم كان قائما على اسس علمية محضـة وانهـ لم يكن يرتكز

* امحوتب : ويعني اسمه الذي يـاتي في سـام ، كان كاهنـا لمعبد مدينة اون (هليوبوليس) ومستشار ا ومعماريـا بار عا للملك زوسر ثناني ملوك الاسرة الثالثة

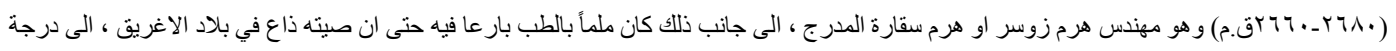

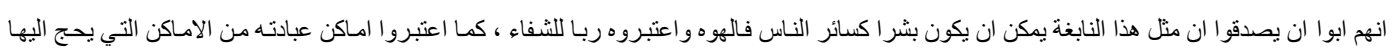

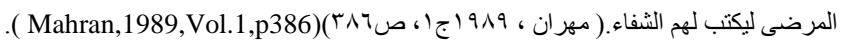

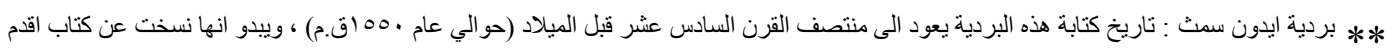

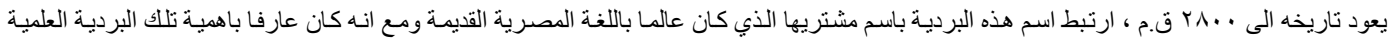

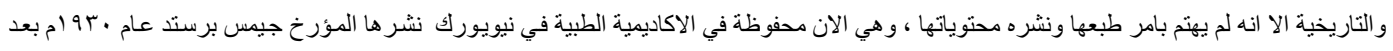

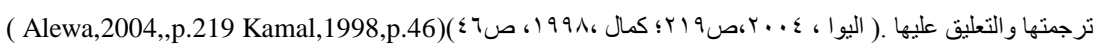
** * وما يؤسف اليه ان نصوص تللك البردية تقف عند العمود الفقري اب انها تفتقر الى الجزء المتعلق بالحوض و الاطر اف السفلية. 
على التعاويذ السـريـة في معظم احواله ، فمحتويات هذا القسم المؤلف من سبعة عشر عمود يضم معلومات مرتبة ترتيبا علمياً منطقياً، فهو عبارة عن بحث في الجراحة خاص بجراحة العظام والعـلاج الظاهري، دون فيها مؤلفها م^ء حالة مرضية وصف فيها تشريح

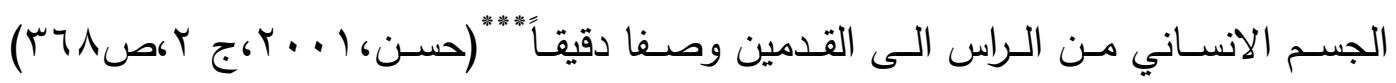

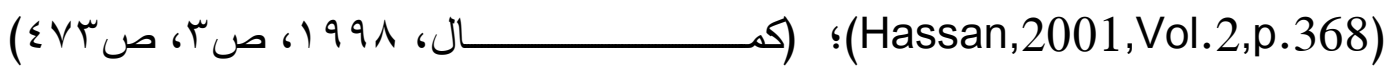
(Kamal, 1998,p.3,p.473)

ولان الحـديث في تفاصسيل تلـك الحسالات يبعـنـا عـن موضـوع البحـث فانتـا نكتفي بالإشـارة الـى مـا ذكـره ناشـر تلك البرديـة المؤرخ جيمس برسـتـ الىى " ان هـا الجزء مـن

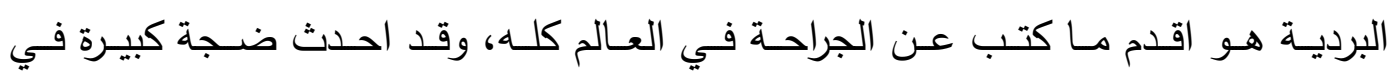

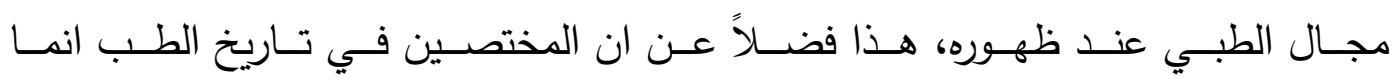
يعتبرونـه نقطـة التحـول بـين فـن العـلاج وعلم الطـب، ذلـك لان محتويـات تلـك البرديـة

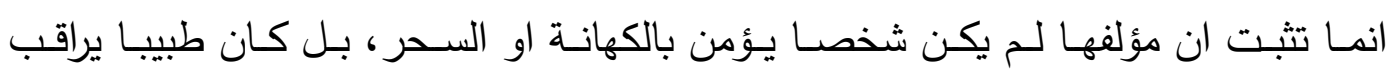

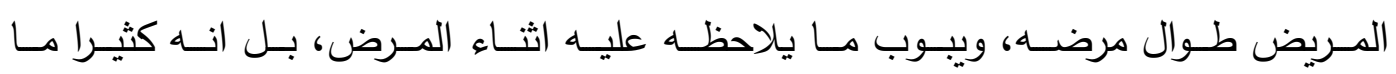

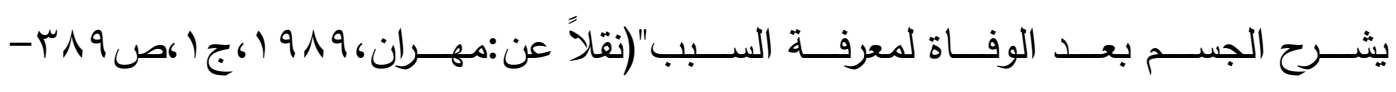
according to:Mahran,1989, Vol.1,p.p.389-390)(

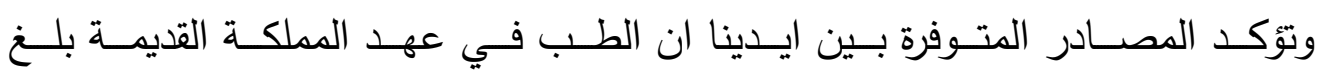
درجـة مـن التقــدم وان الاطبـاء كـانوا ينقسـون علـى فئـات مختلفـة مـن حيــ العدـل ومـن حيـث التخصـص، فمـن حيـث العهـل كـان هنـاك اطبـاء موظفـون، ومـنهم اطبـاء القصـر ، ولا شــك انهـم مـن الاطبــاء المهـرة مدـن يحمـل احـدهم لقـب كبيـر الاطبـاء،

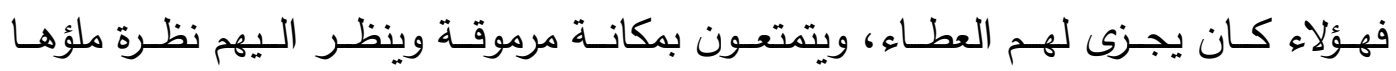

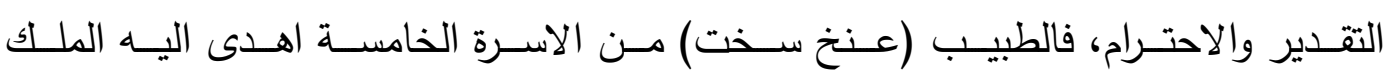
(سـاحور رع) بابـا وهميـا مـن الحجـر الجيـري المـزدان بـالوان مـن الحجـارة الكريمـة وامـر

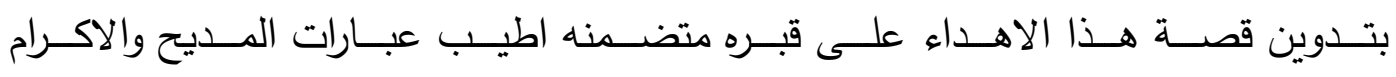

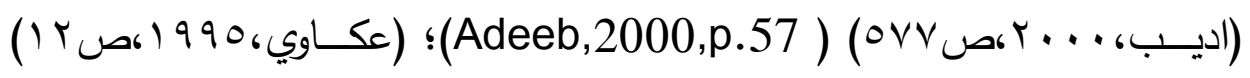

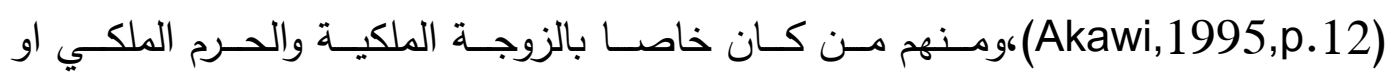

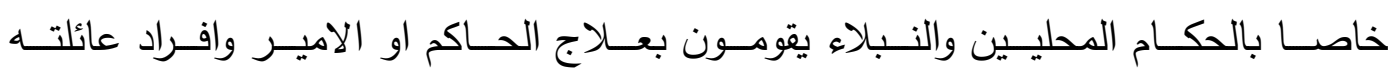

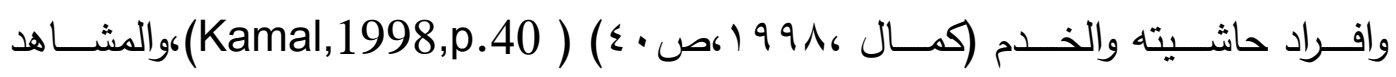

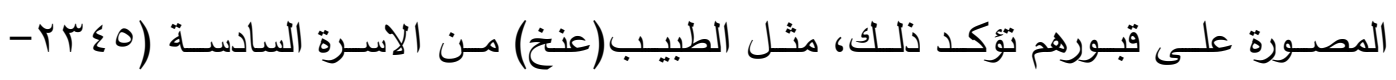




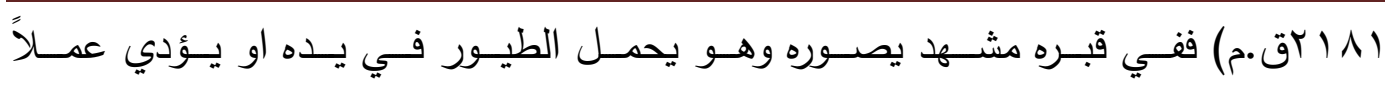

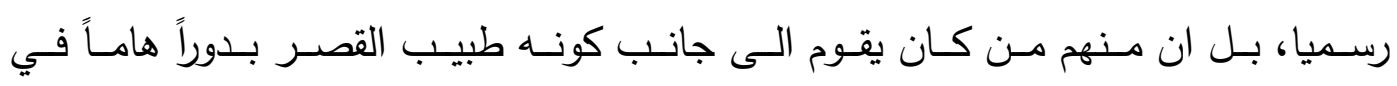

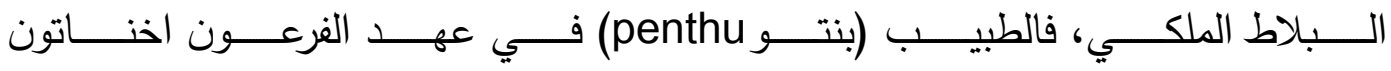

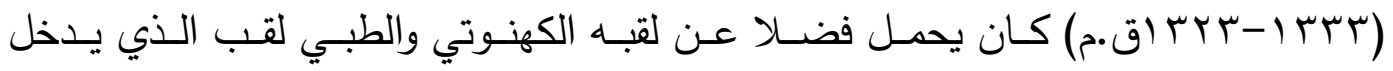

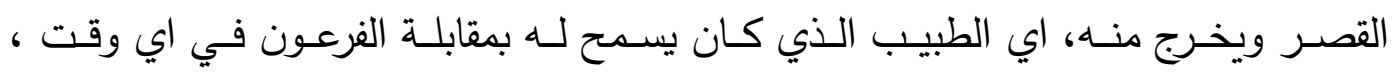

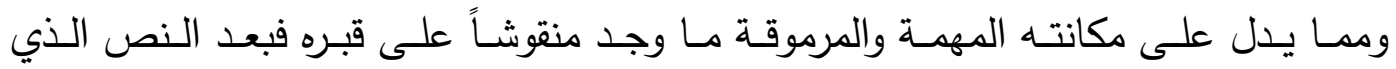
كتب فيسه اسـمه مشـهـا يصوره وهو ممسكا بيده سـوطا بوصفه دليلا على القوة والجـاه

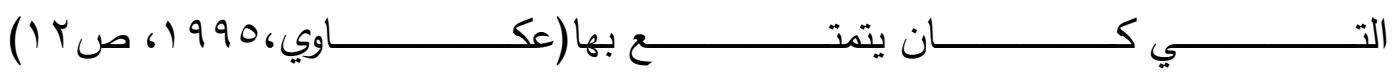

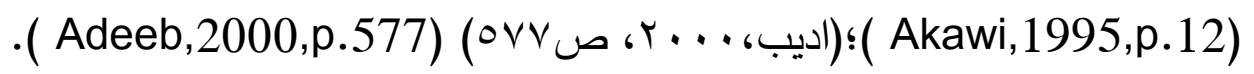

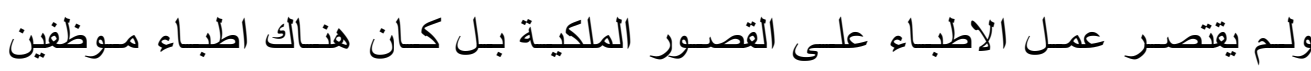

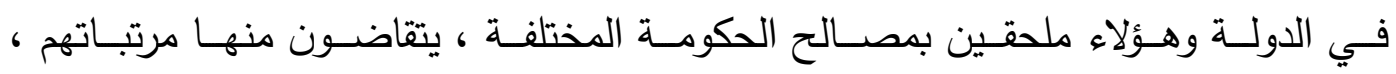

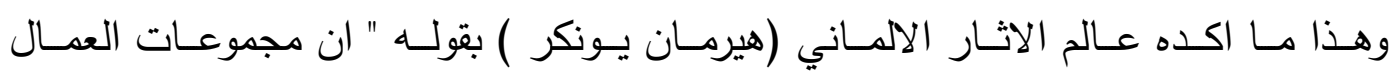

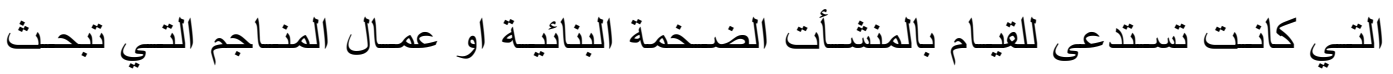

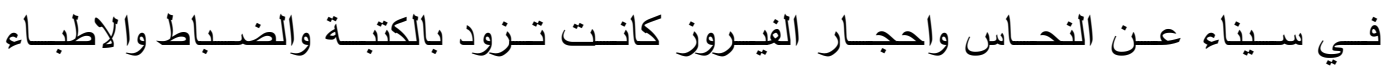

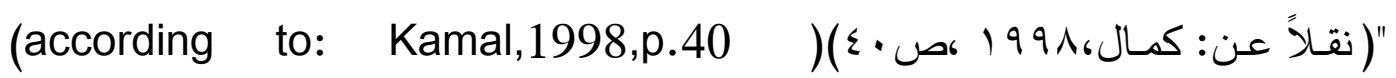

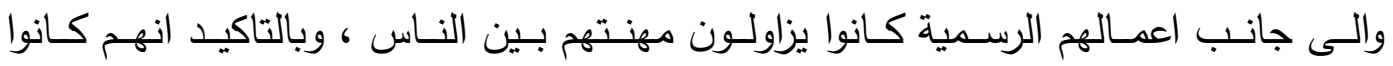

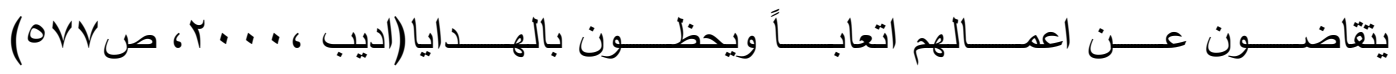

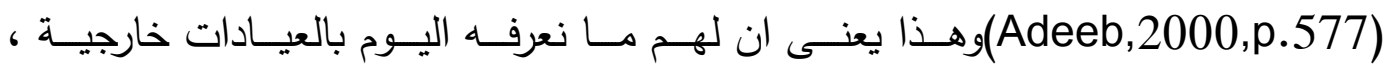

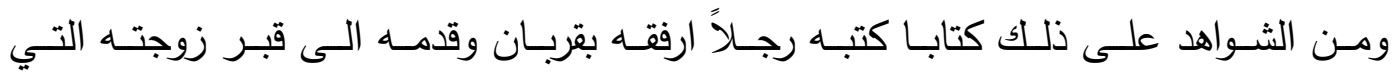

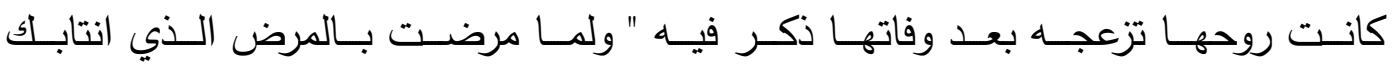

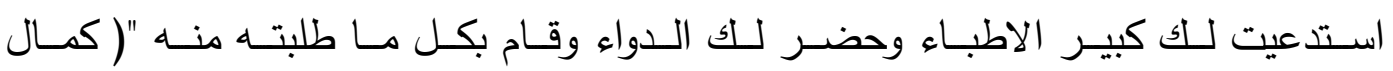

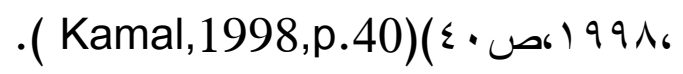

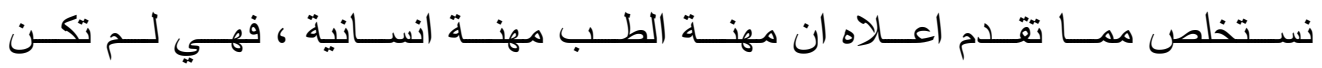

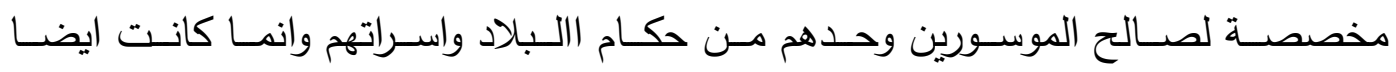

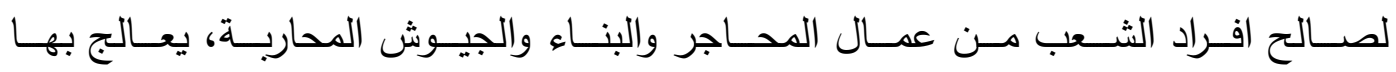

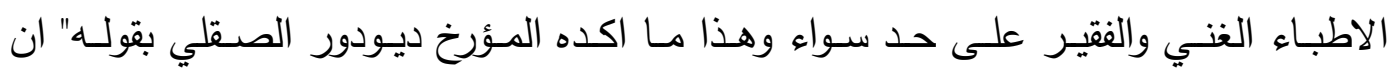

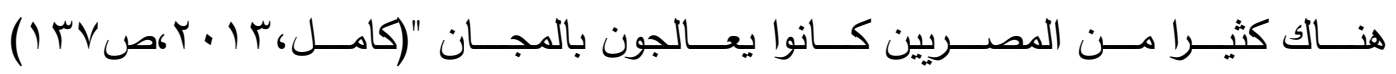

.( Kamil,2013,p.137)

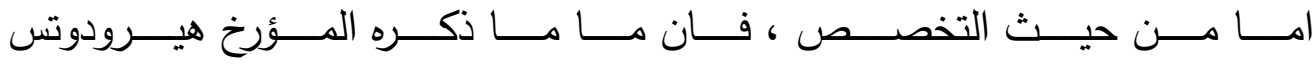

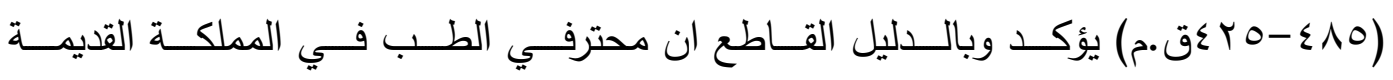




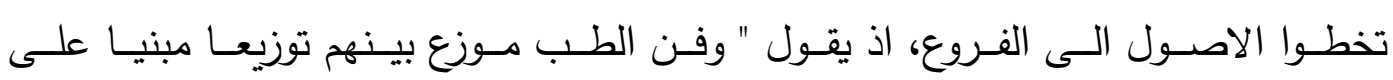

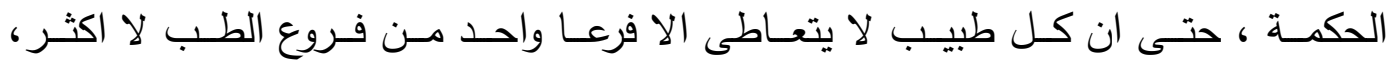
والاطبـاء هنــا كثيـرون جـدا فــنهم للعيـون ومـنهم للـراس ، ومـنهم للأسـنان، ومـنهم

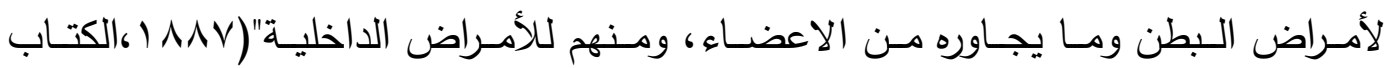

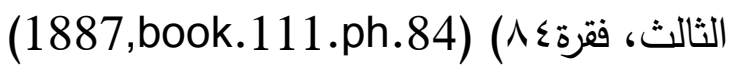
واقدم طبيبب متخصص ذكرته المصادر هو (حسى رع Hesy ra) من الاسرة الثالثة ،

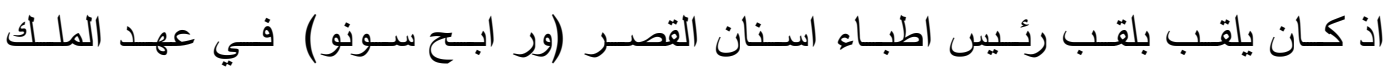
زوسر (1^צ التي عثر عليهـا في مقبرتـهـ في صـقارة والمحفوظـة الان في المتحفف المصـري في

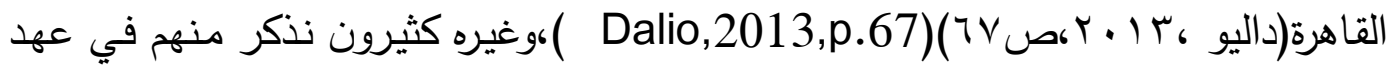

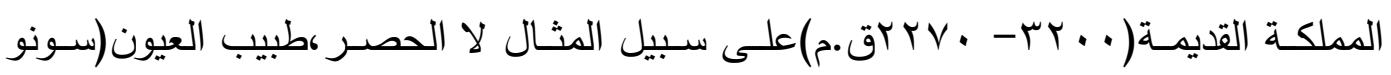
ايرتي) اي اخصـائي العيون الطبيبب(ني -عنخ دواو) ، والطبيب (مدو نفر) رئيس اطباء

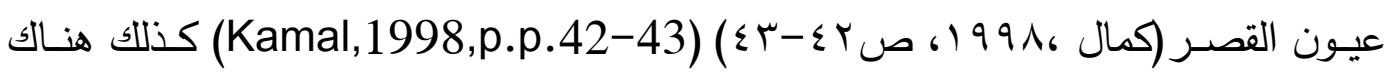
الطبيب المختص في منطقة البطن (سونو خيت) اي اخصـائي الجهاز الهظمي ، وحارس المؤخرة اي اخصـائي امراض الشـرج، وطبيب خـاص بطب النسـاء والتولد ..التخ( داليو،

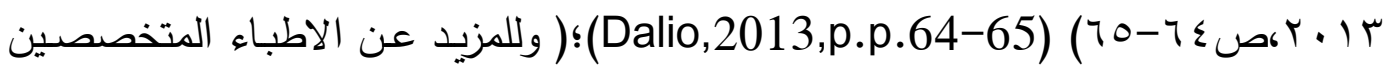

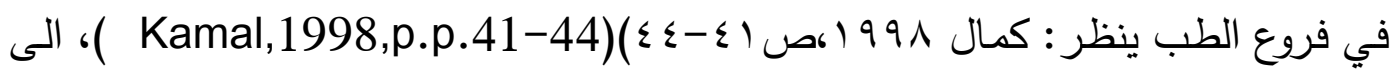
جانب هؤلاء مـن اصـحاب الاختصـاص كـان هنـالك طبيـب عـام جـع بـين عدد مـن هذه التخصصـات ومنهم رئيس الاطباء ايري نختي Iry الذي كثف عن مقبرته عـالم الاثار الالماني (يونكر) فكان مكتوب على شاهد قبره انه طبيب وعميد اطباء البلاط واخصائي في

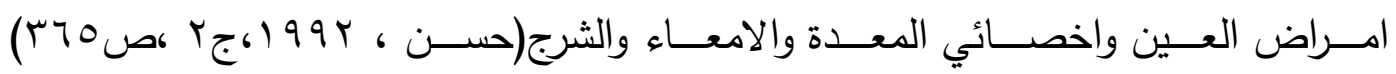

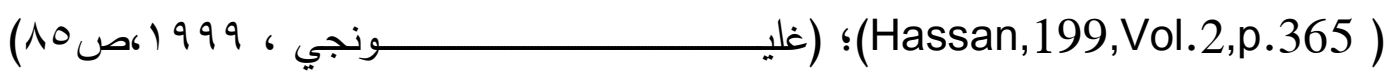

.( Galungi,1999,p.85)

ومعرفـة قـدماء المصـريين بالطــب مكنـتهم مـن التثريـق بـين الطبيــب المخـتص والمحترف غيـر الطبيـب ، فالطبيـب (منكـاورع عنخ ) لقـب (ايـري ايـح) ومعنـاه صـانع الاســنان لتميـزه عـن ( نـي عـنـخ سـخمت) مـن الاسـرة الخامسـة ، الـذي رسـم على

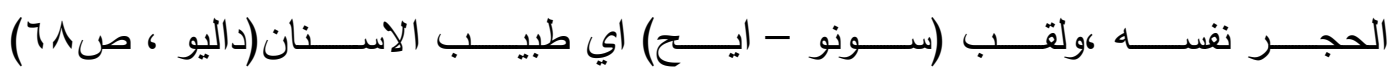

.( Dalio,p.68)

ولـم يقتصـر الامـر على حـد التخصـص بـل ان الاطبـاء كـانوا يتـدرجون في اطـار وظـائف ترتيبيـة تصـاعدية في الادارات الحكوميـة مسن درجـة طبيـب الى كبيـر الاطبـاء 


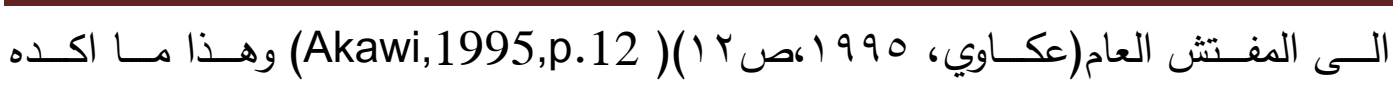
الاثـاري (يــونكير ) بقولـهـ " ان الاطبـاء كـانوا مقسـمين الـى درجـات بمـا يتماشـى مـع كـادر المـوظفين او كـادر الكهنـة ، فقـد كانــت اربــع درجـات هـي اولاً - الطبيــب العـام غيـر المتخصــص فـي فـرع مـن فـروع الطـب، ثانيـا -كبيـر الاطبـاء ، ثالثـا مفـتش

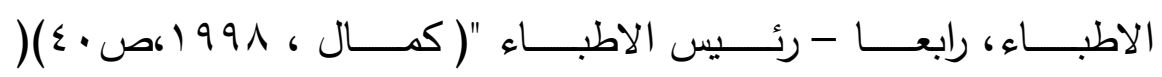
- (Kamal, 1998,p.40

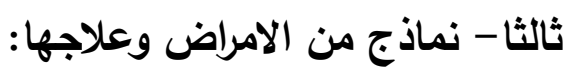
ان مـا وجــد فـي البرديـات الطبيـة يــدل علـى ان المصــرين عرفـوا الكثيـر مـن

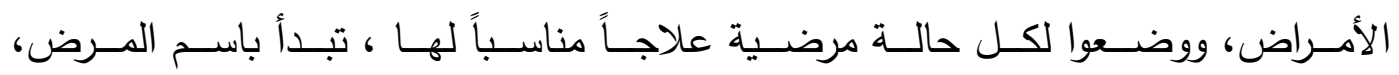
والادويــة يعـدها الطبيـبـ بنفسـهـ علـى شـكل شـراب او مغلـي او منقـوع او مـرهم او غسـول او قطـرة ،ويـذكر طريقـة الاسـتعمال ، هـل يؤخـذ الـدواء قبـل او بعـد الطعـام،

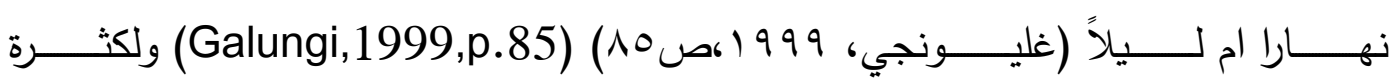
الأمـراض التي تعرضـوا لهـا، فأنتـا سـوف نقتصـر على ذكر بعضـها على سبيل المثال لا الحصر مع ذكر العقاقير الطبية التي كانوا يعالجونها بها. ا - الأمراض التي تصيب الشعر والرأس .

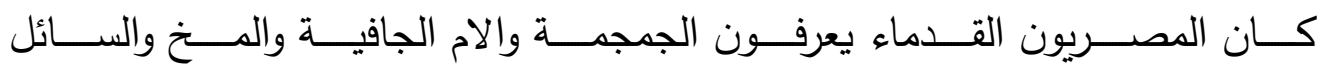
النخـاعي، وكـانوا يعتقـدون ان هنـالك اربعــة شـرايين تمـده بالغـداء مـن ناحيـة وتسـبب

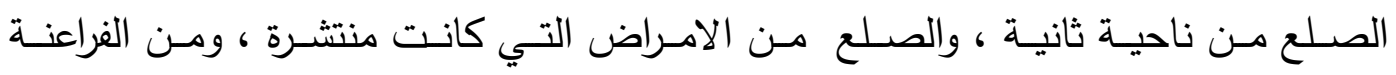

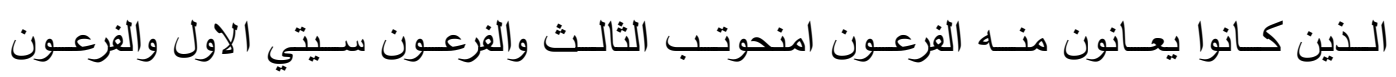
رميسـي الثاني،كمـا كانــ الملكـة نفـر تـاوي (نغرتيتي زوجـة اخنـاتون) تعـاني مـن تسـاقط

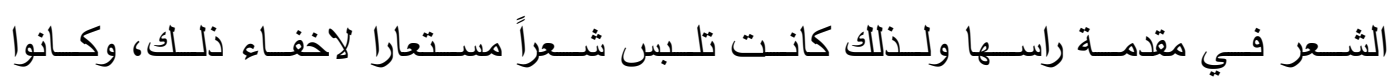
يعالجونـهـ بـدهن الـراس بزيــت الخـروع مخلوطـاً بادهـان التمســاح والقـطـ والثعبـان والتيس البـري، وكــللك بمخالـب الكلــب وحـافر الحمـار (وهـي فـي الغالـب مـن الحشــائش)

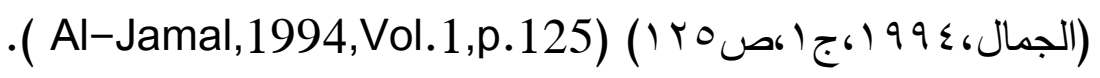

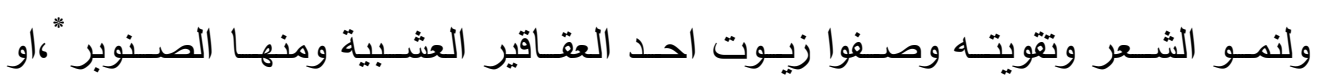

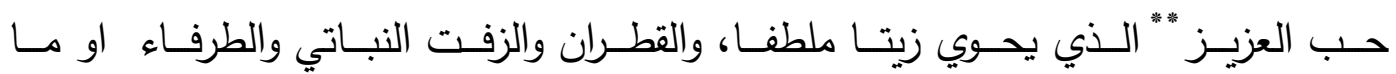

* الصنوبر يستخرج منه مادة تسمى الر اتتج (مادة سائلة لزجة تشبه الصمغ تستخدم بكثرة في صناعة البويـاو الصسابون ) ، ومادة زييتية تعطي زيت التربنتين

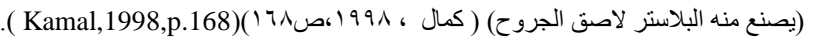

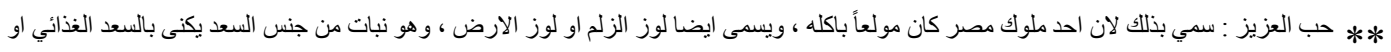

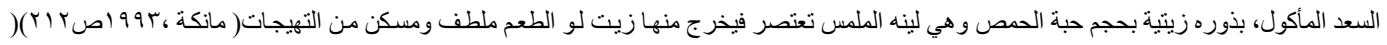


يســى بـ الاثلـل اذ يتولـد عليـه نـوع مـن العفـص يسـمى البجم، تسـتعمل الوصـفة طـلاء

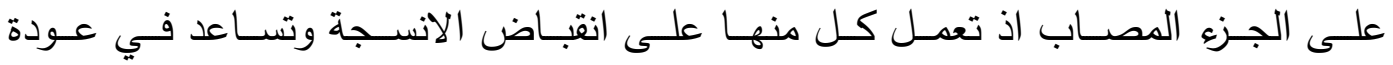

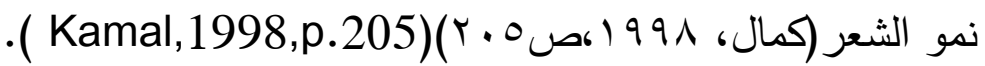
ومسن الامـراض الجلديـة التـي تصـيب فـروة الـرأس (الهبريــة) وهـي قثــور تشـبه

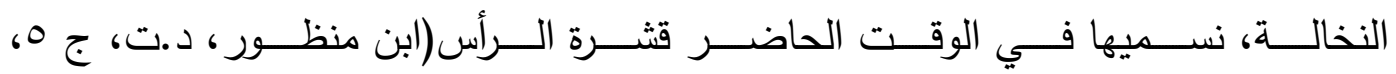
صهץr) ( Ibn Mandhor,N.D, Vol.1,p.335) اسـتعملوا في علاجهـا عـدة عقـاقير نباتيـة منهــا دهـن فـروة الـراس بخلـيط مـن احـد الادهــان ممـزوج بمسـحوق الشــعير المحمـص ومســحوق الخلــة (الحنطــة) المحمص،واسـتعملوا الحنــاء ، كـذللك كـان يوصـي بـدهن راس المصــاب بزيـــ الســك (وهـو مـن الوصـفات التي تسـتعمل

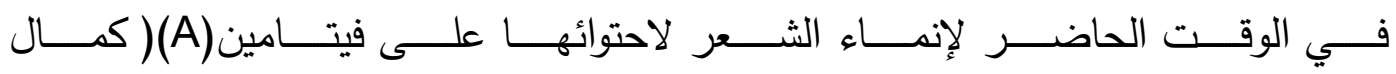

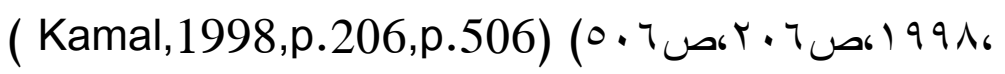

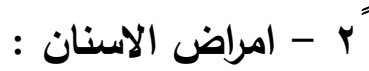

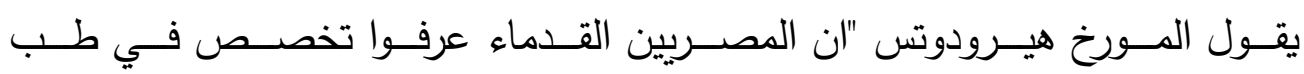
الاســنان، وان اخصــائي الاسـنان كـانوا علـى درجـات مختلفـة، فمـنهم الطبيــب العـادي

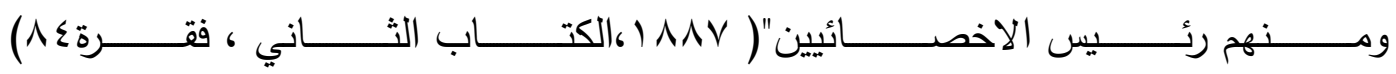

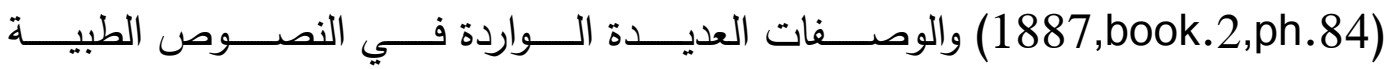
الفرعونيـة تؤكـد ذلــك ،فيـذكر ان الملـك امنحوتـب الثالـث لـم يكـن يتحمـل الام اسـنانه

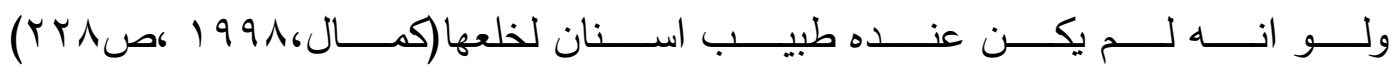
.( Kamal,1998,p.228)

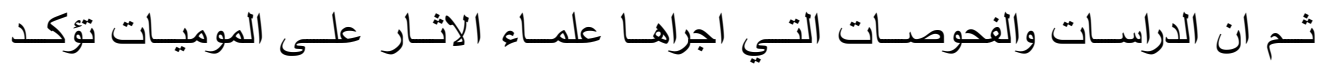
براعـة المصــرين القـدماء فـي طـب الاســنان وقـدرتهم علـى اسـتعمال مـواد مهــة في الحفـاظ عليهـا ومعالجتهـا ، فالمؤميـات المصـرية التـي اجـرت عليهـا الابحـاث اكـدت ان مـرض تسـوس الاسـنان لـم يظهـر الا فـي عهـد الدولـة الحديثـة ( •OV اق.م) فحالـة اســان اهـالي مصـر والنوبـة كانـت جيـدة بسـبب بسـاطة الطعـام الـذي كـان اغلبـه نبـاتي ويحتـوي علـى مــادة السـليوز ، ومــع زيــادة التـرف وتتــوع الطعــام ظهـرت حــالات

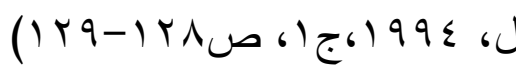
(الجم (1) (1) (1) التسـ (Al-Jamal, 1994,Vol.1,p.p18-129) وقــد احتـوت برديـة ايبـرس الطبيــة علـى وصــفات عـدة لحشــو الاســنان ومنــع تسوســها معظمهــا كانــت تتكـون مـن مسـحوق لبعض المـواد معدنيـة او الاحجـار التي لهـا اثـر في ايقـاف التسـوس مثل الملاخيــ، واكاسـيد الحديـد (المغـرة الصـفراء) بعـد خلطـه مـع العسـل او عقـاقير نباتيـة لهـا صـفات 


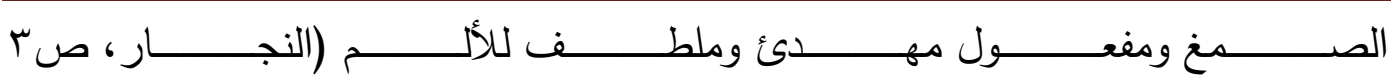
،(Al-Najar,p.3 ) ( www.ahram.org.eg/NewsPrint/322911.aspx

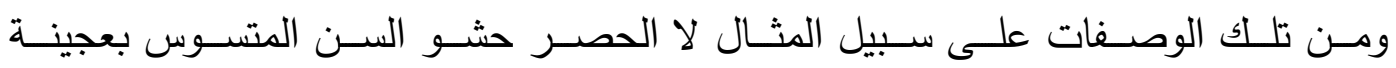
تتكــون مـن خلـط مسـحوق المغـرة الصـفراء و والملخيـت وعصـير السـنط" (السيسـبان)

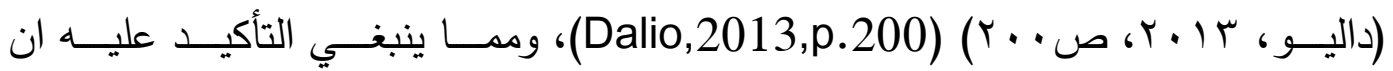

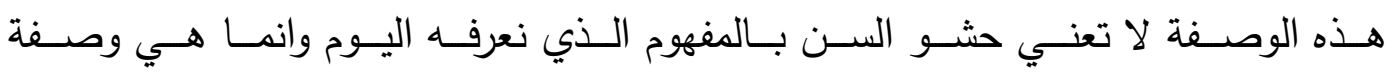
استعموها لمداواة الآم الاسنان المتسوسة.

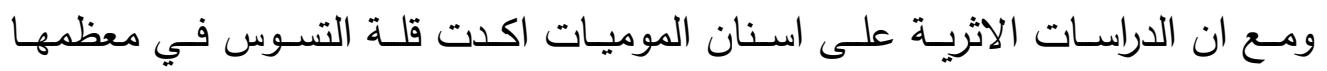

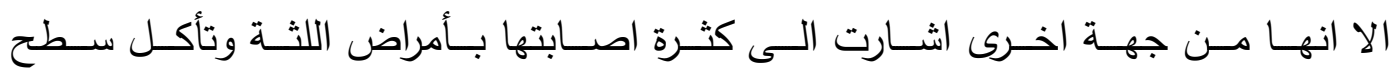

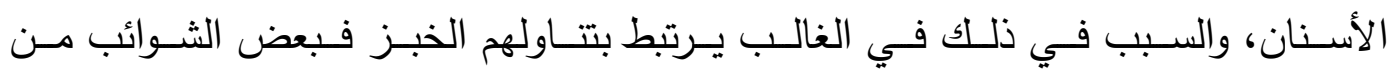

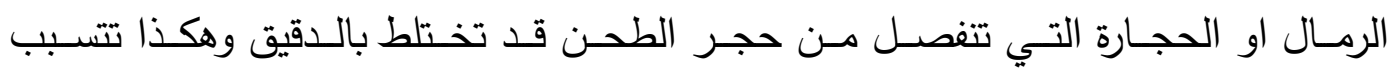

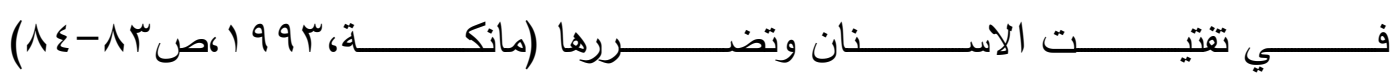

( Manka,1993,p.p.83-84)

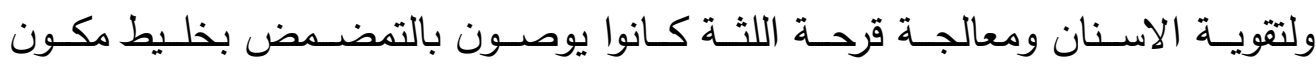

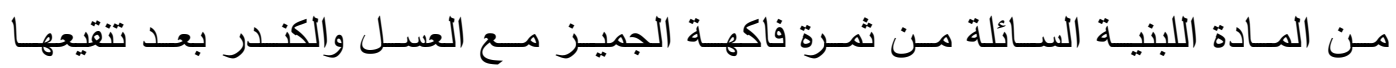

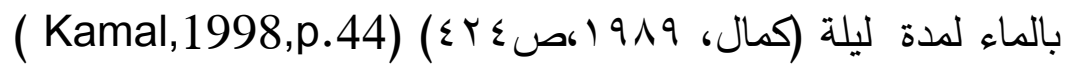

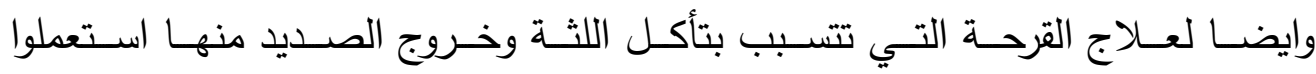

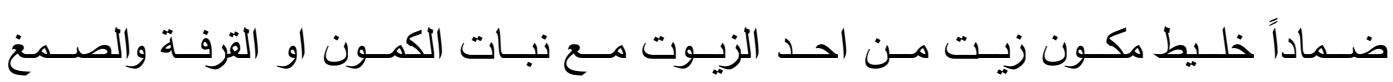
(19r-19) (مانك (ك) ون ون العربي(الس ضي ( Manka,1993,p.p.191-192) وكذللك استعملوا ضـمادا على السـن خليطـا مـن

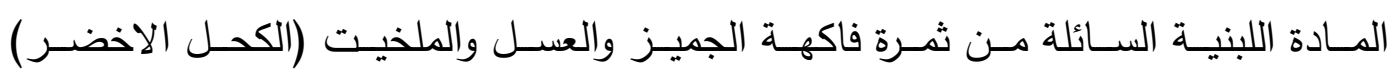

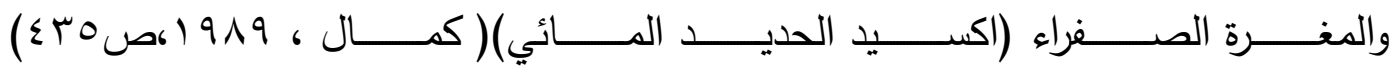
( Kamal,1998,p.435)

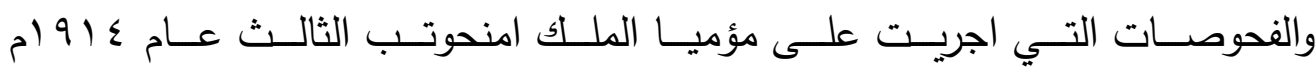

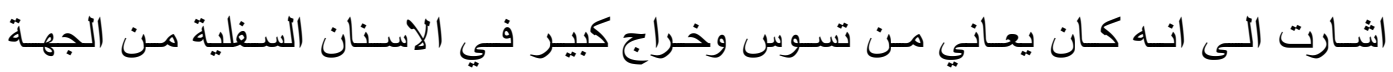

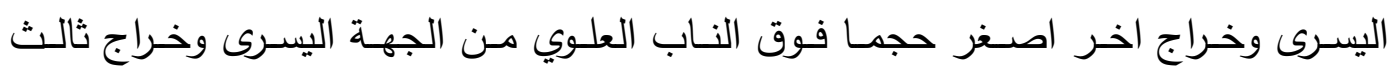

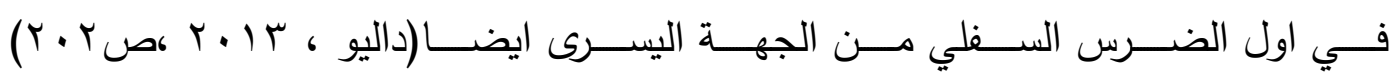

(Dalio,2013,p.202)

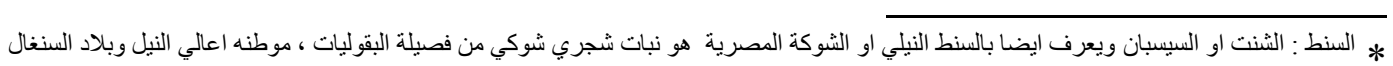

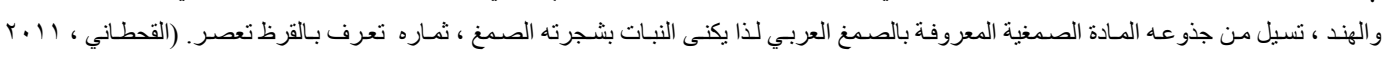

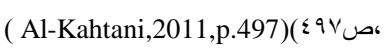


ويبـدو انهم لجـأوا الـى الجراحسة للـتخلص مـن ذلـك الخـراج فهنـالك مـا يشـير الـى

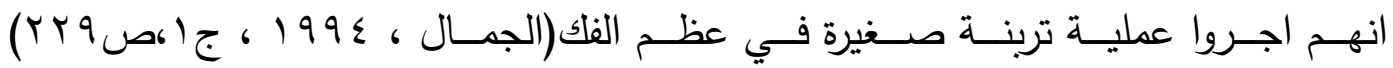
(Al-Jamal,1994,Vol.1,p.229)، يؤكـــد عثــور الباحـث الاثــاري فلنـدرس بتــري في مدينـة ابيدوس عاصـمة مصـر الاولى على فلك يعـود الـى الاسـرة الاولى او الثانيـة محفـوظ فـي الوقـت الحاضـر في المتحـف البربطـاني ، يظهـر فـي هـــا الفـــ خراجـا حـول قــة الضـرس الاول مـن الجهـة اليسـرى مـع وجـود ثقب جراحسي ، كذللك عثر في عـام VI VI ام عثـر علـى فـك سـفلي لرجـل متوسـط السـن مـن زمـن الاسـرة الرابعـة

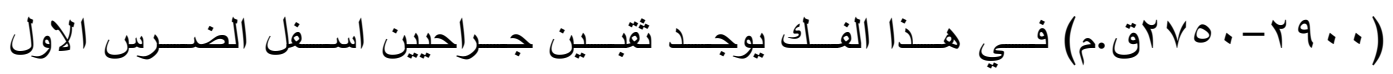

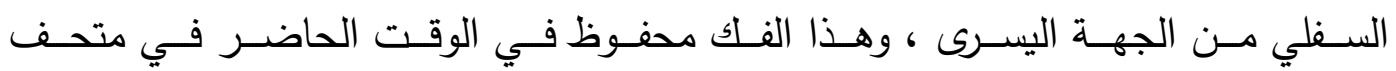

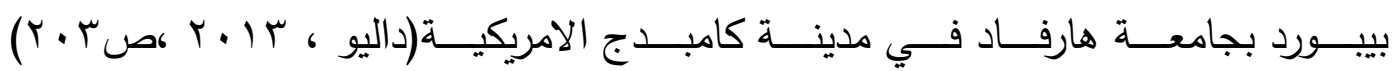

(Dalio,2013,p.203)

ليس هذا فحسب بل ان هناك ما يؤكد انهم اجروا اخطر العمليات الجراحية التعويضية

المعروفة في الوقت الحاضر (زراعة الاعضاء) ، فمن خلال فحص احدى المؤميات وجد ان الطبيب الفرعوني قام بإعادة احد الاسنان الى مكانه بعد ان قام بربطه بالسن الثابت المجاور

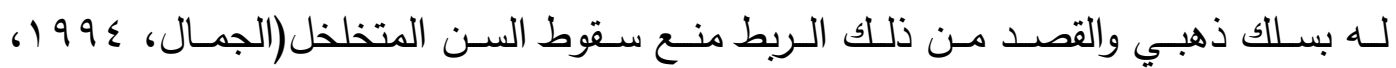

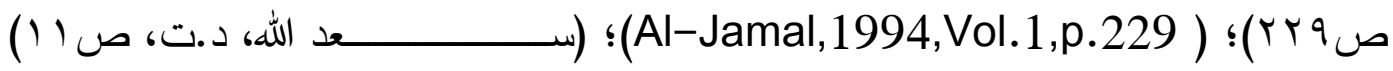
وعلى الرغم مما قيل عن مهارة قدماء المصريين في جراحة

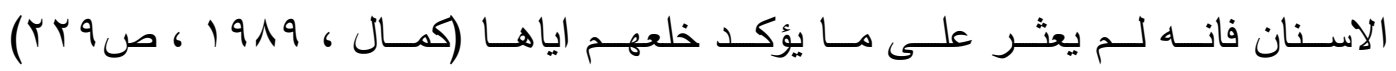

( Kamal,1998,p.229)

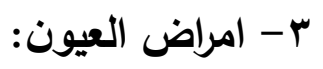

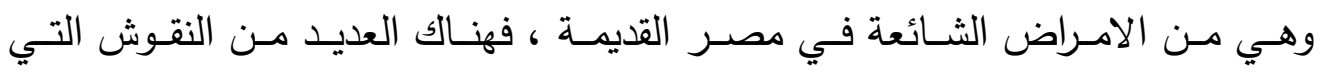
يظهـر فيهـا المكفـوفين وهـــ يزاولـون الغنــاء او الموسـيقى ، وربمـا كـان تـدريبهم على هـذا النـوع مـن الفنـون نوعـاً مـن التأهيـل المهنـي ، ووهـع ان برديـة ايبـرس الطبيـة ذكـر

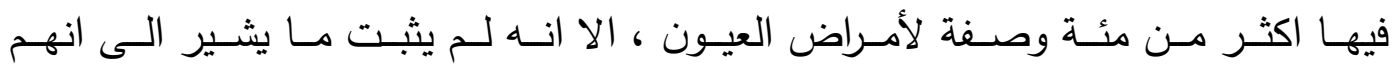

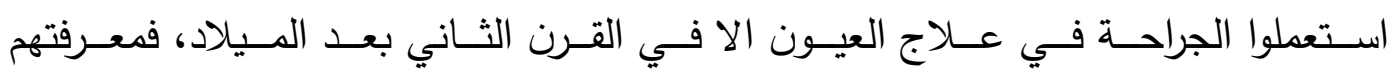

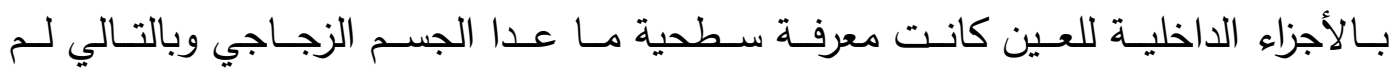
يطلقــوا عليهــا اســماء، وكـانوا يسـمون الحدقــة بــ(الفتاة التـي داخـل العـين) وكـانوا يعتقــدون انهــا منبــع الــدموع امـــا الجفــن فكــانوا يطلقــون عليــه (ظهــر العــين)

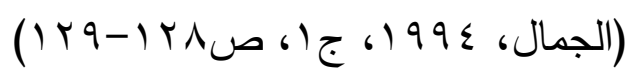
(Al-Jamal,1994,Vol.1,p.p.128-129) 


$$
\begin{aligned}
& \text { ومن الامراض التي وصفوها وعالجوها هي } \\
& \text { أ-الرمد او التراكوما : }
\end{aligned}
$$

يعـرف باللغــة المصـرية القديمـة( نحـات Nehat) ويعنـي تكـوين حبيبـات ـ وهـو

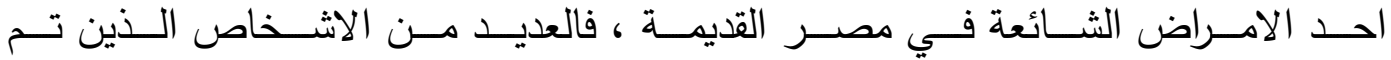

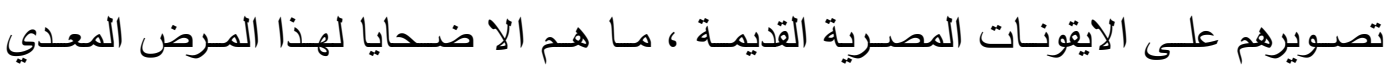

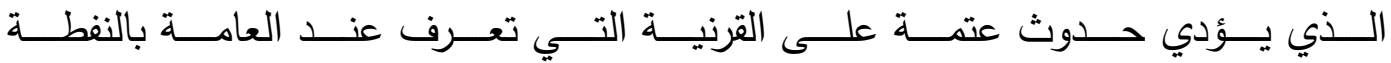

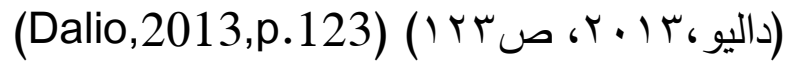

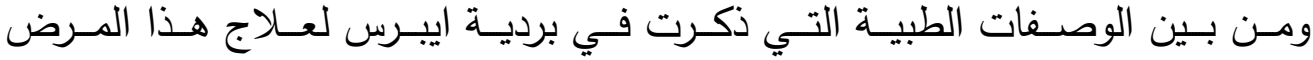

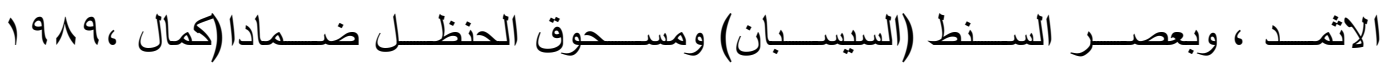

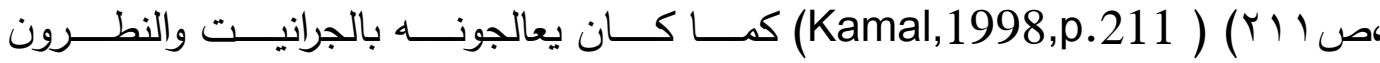

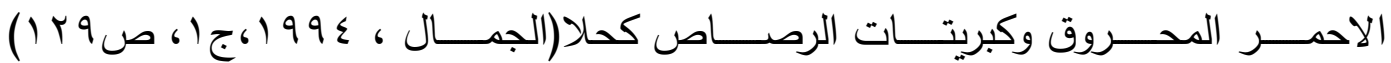
(Al-Jamal,1994,Vol.1,p.129)

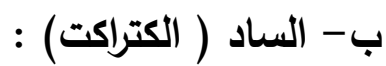

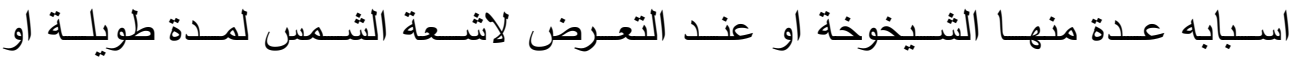

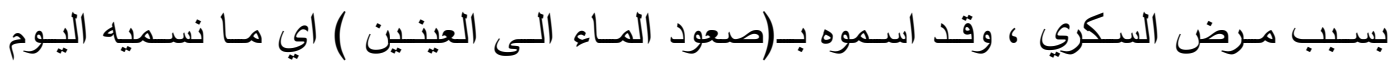

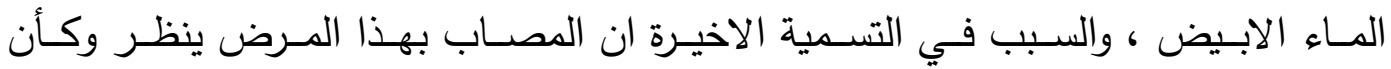

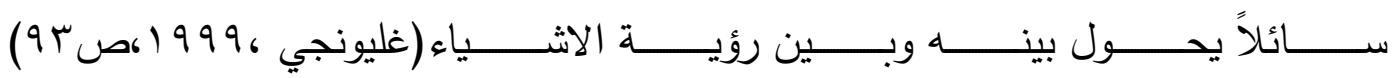

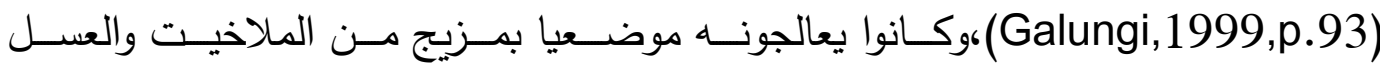

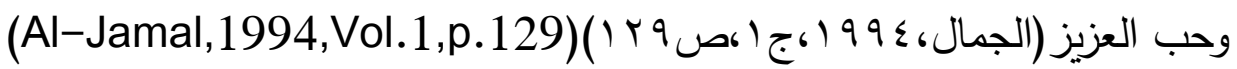
ج - التهاب الجفون : التعزيز

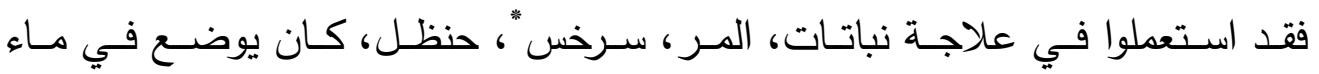

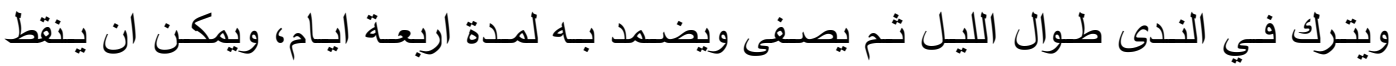

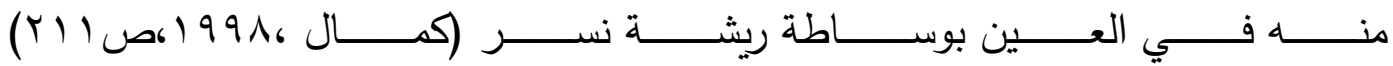

(Kamal,1998,p. 211)

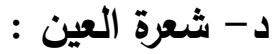

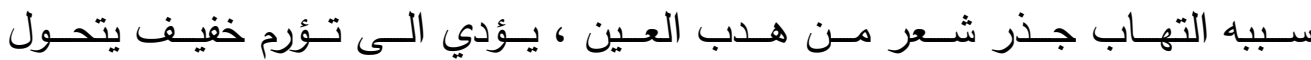
تـدريجيا الـى حبـة متقيحـة ، ويشـعر المصــاب بوجـود شـعرة فـي عينـهـ تحسول دون

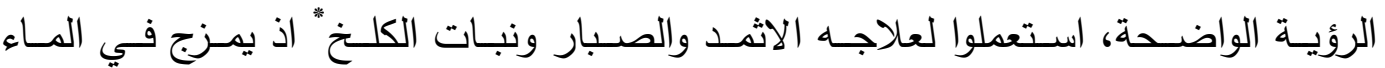

* سرخس او الخنشاروهو من نباتات السرخسية

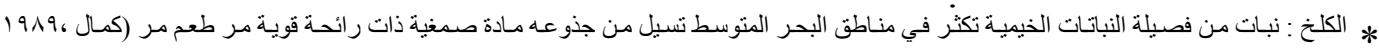
( Kamal,1998,p.157) 
(r) r-r)1 1919، UL

(كين (-

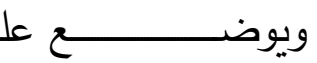

( Kamal,1998,p.p.211-212)

هـ - العثى الليلي :

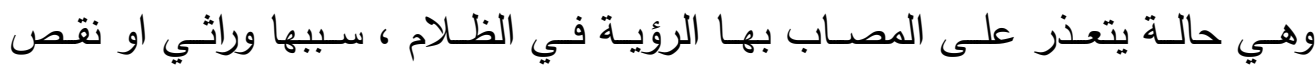

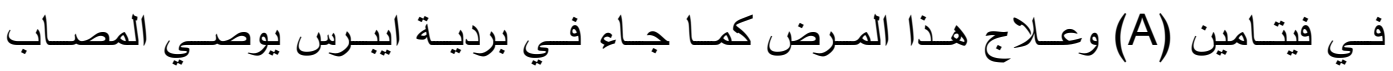

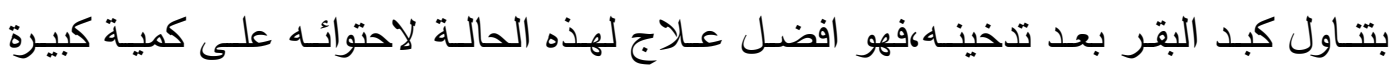

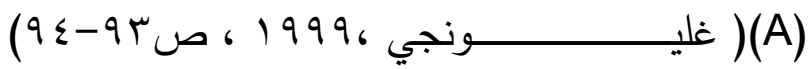

.(Galungi,1999,p.p.93-94)

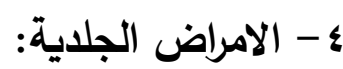

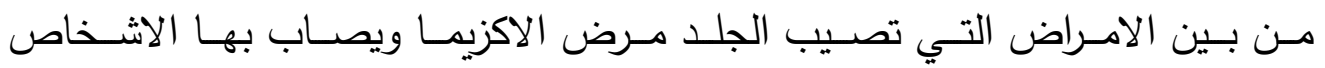

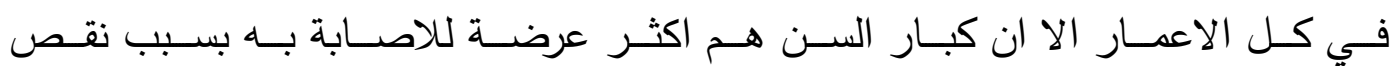

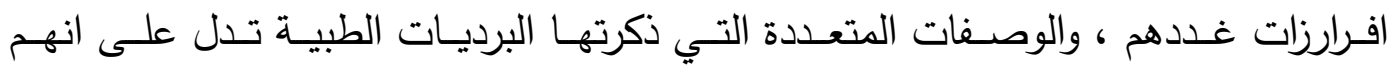

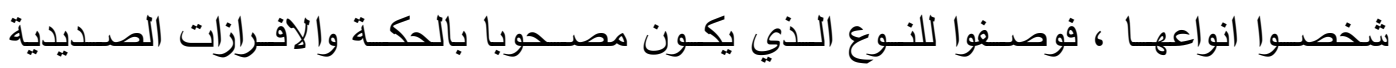

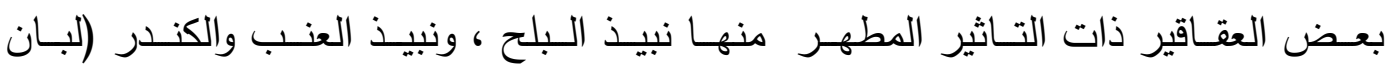

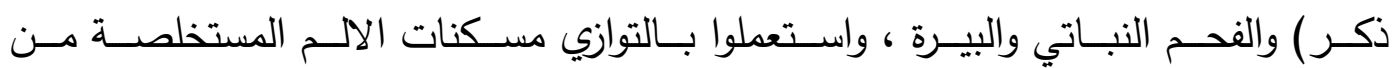

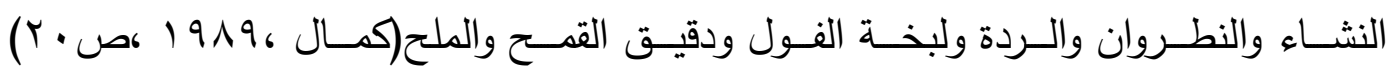

( Kamal,1998,p.20)

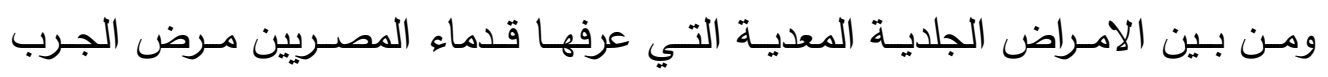

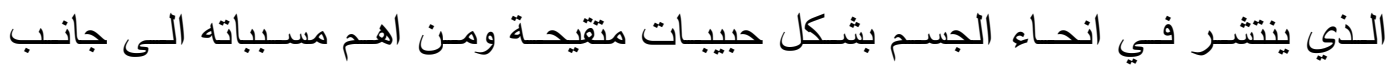

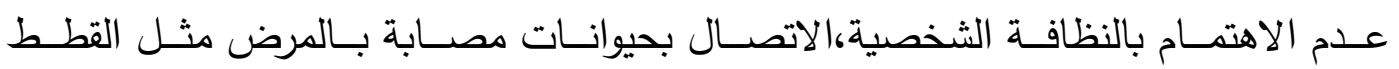

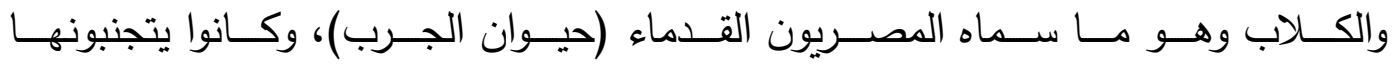

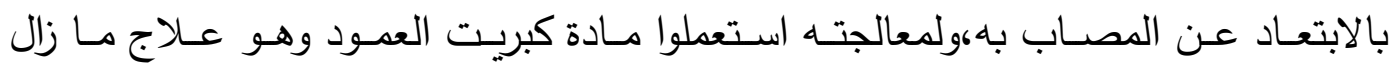
يسـتعمل الـى الوقت الحاضـر بـين العامـة،ومن العقاقير التـي وصـفت لعلاجـهـ البـابونج

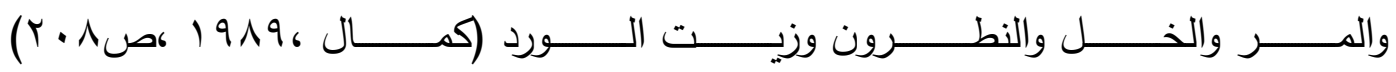

(Kamal,1998,p. 208)

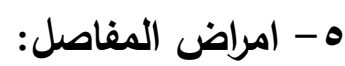

ولعـل اكثرهـا شـيوعا مـرض (ستت ) وهـو مـرض يصـيب المفاصـل لاسـيما عظــام

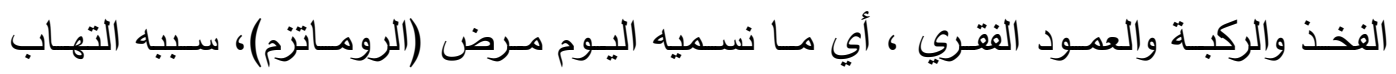

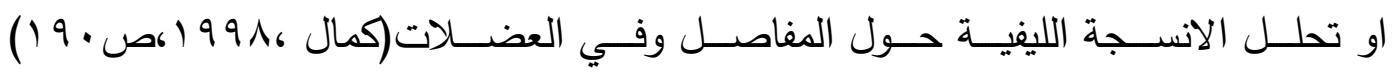

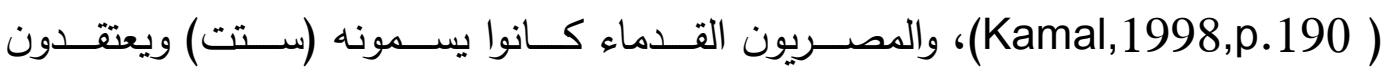


ان سـببه الخلـط او الـبلغم ولـذلك اسـتعملوا للحـالتين لفظـا واحـدا ، وقـد اكـدت ابحـاث الاثـارين التي اجربــت علـى الموميـات فـي مصــر والنوبـة ان هــذا المـرض مـزمن

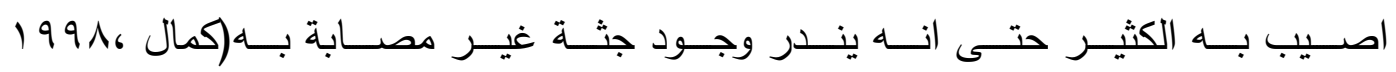

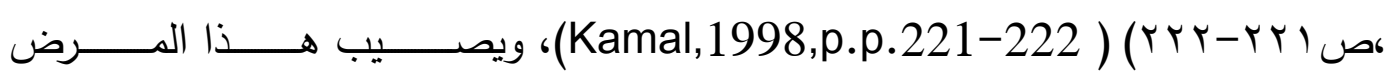
منطقـة العنـق ايضــا فقـالوا في تشخيصــه " اذا فحصــ شخصـا مصـابا بالرومـاتزم في عنقـه ، وهــو يتـالم مـن عضــوي اي جـانبيي عنقـه ومـن راســه ووجـدت فقـرات عمـوده الفقري متيبسـة وعنقـه ثقيلا ويتعــر عليـه مشـاهدة بطنـه لمـا يصـاحب هـذه الحركـة مـن

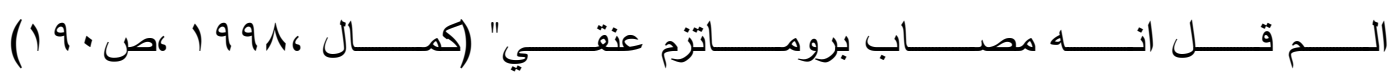

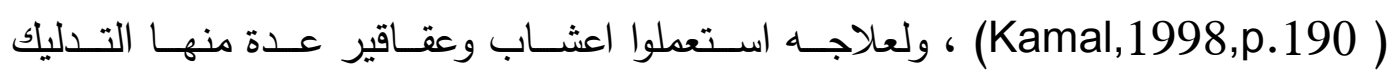

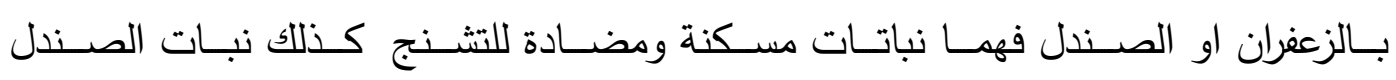

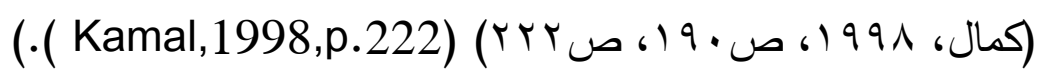
צ- الجروح والأورام والكسور :

مـن الأمسور الطبيعيـة التـي تعلمهـا المصـريون القـدماء في مجـال الطـب معـالجتهم

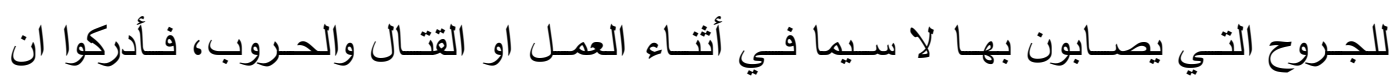
نـزف الـدم قد يـؤدي الحى المـوت ، فـلا بـد والحسال هـهـ مـن اتخـاذ تـدابير سـريعة لإيقافـه

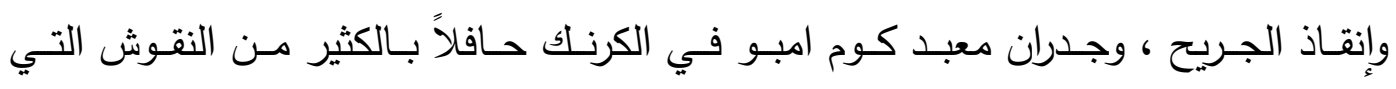

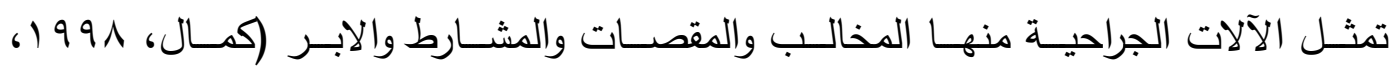
ص اسبr) ( Kamal,1998,p.231) ، ولعــلاج تلـــ الجـروح اســتعملوا عـدة طــرق

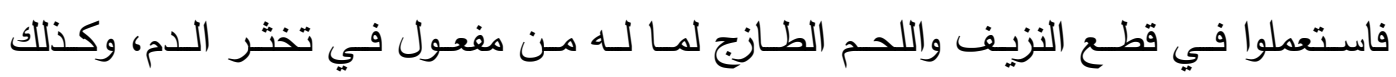

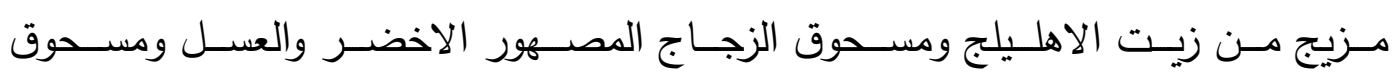

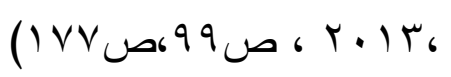
(د)

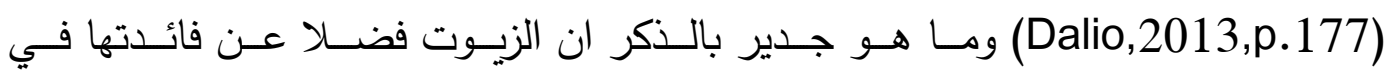

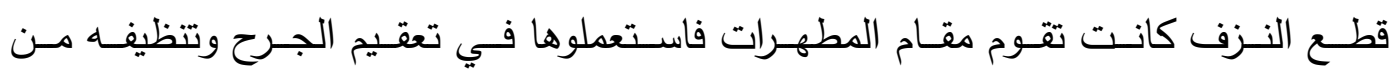

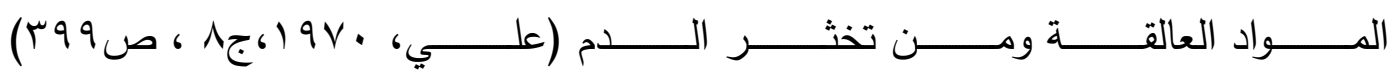

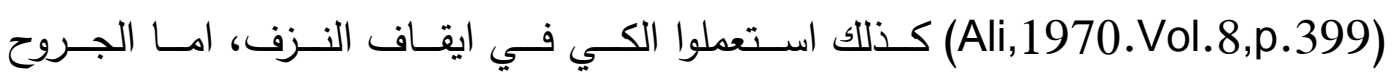
الملتهبـة المتقيحـة فيعالجونهـا باسـتعمال الفتائـلـل لاخـراج التقـيح فـاذا كــان الافــرارز

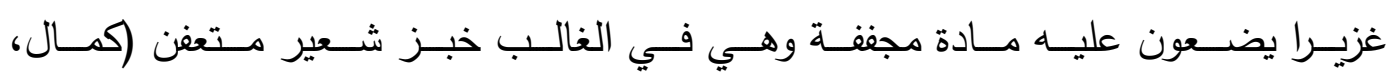

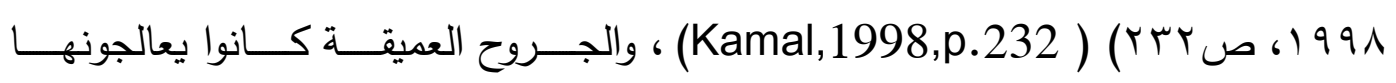

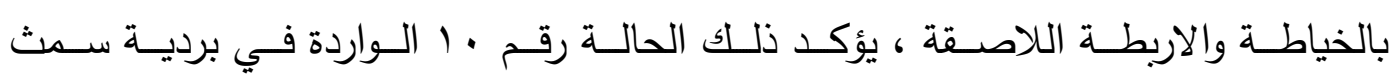

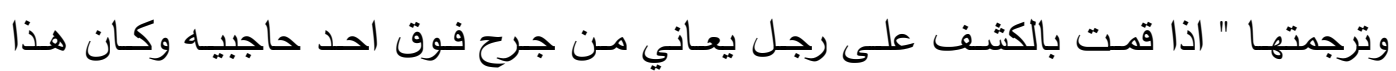


الجـرح غـائرا ويصـل الـى العظم .. عليك ان تتحسس الجرح ثم تحساول ان تقرب بـين

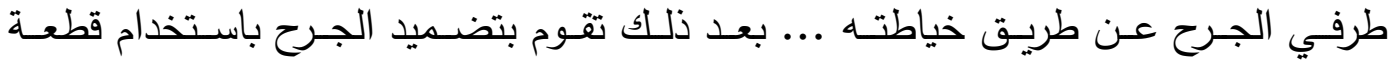

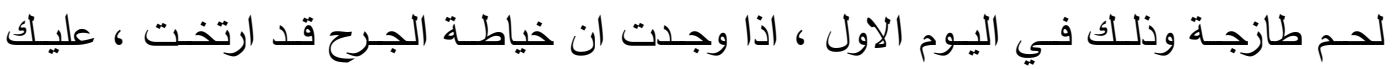
ان تعـاود التقريب مـرة اخرى بـين طرفي الجرح باستخدام شـريط لاصـق ، ثم تقوم بعد

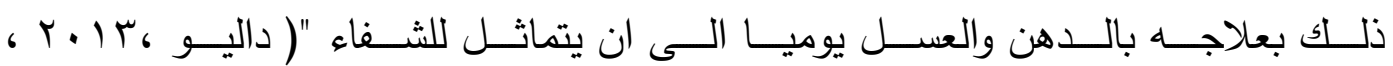

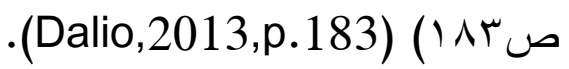

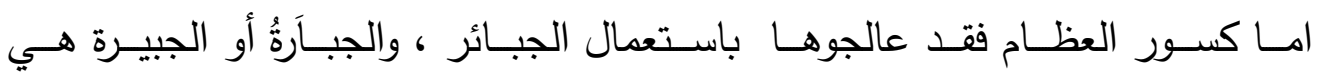

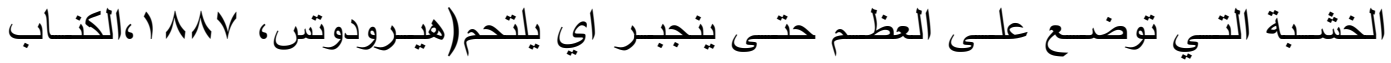
الثاني، الفقرة ع • () (Herodotus ,1887,book.2,ph.84).

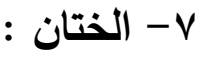

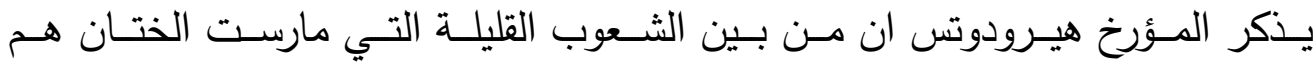

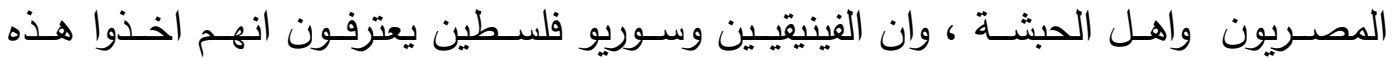

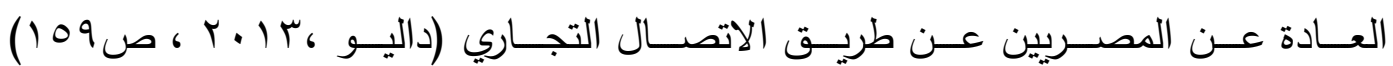
.(Dalio,2013,p.159)

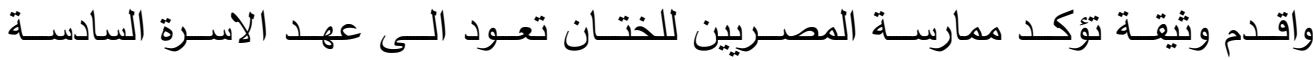

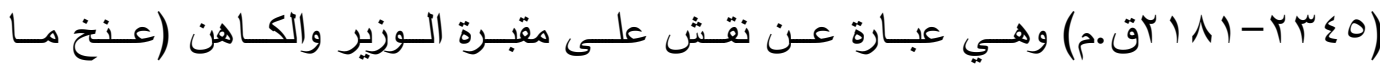

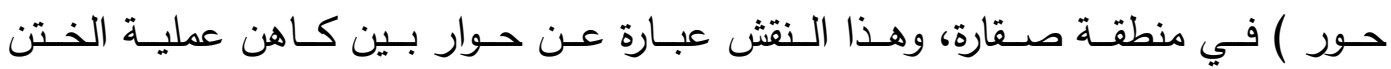

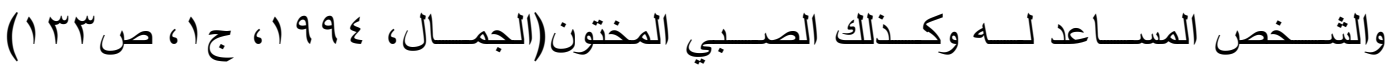
(Al-Jamal,1994,Vol.1,p.133)

وعمليـة الختـان كانـت تجـري لـلاولاد غالبـا بـين سـن السادسـة والثانيـة عشـرة مـن

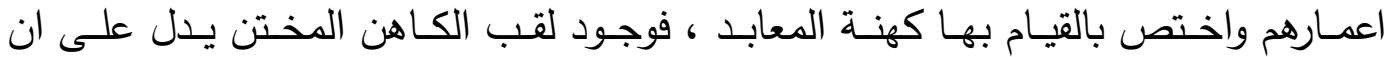

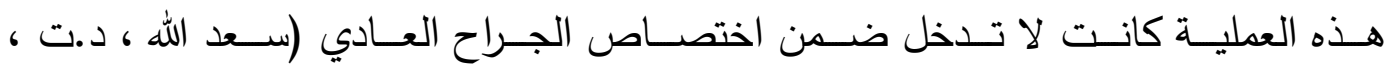
(Sa'ad Allah,N.D,p.10) (1) والـراجح ان الكـاهن المخـتن كـان يسـتعمل مـادة مخـدرة قبـل اجـراء عمليـة الخـتن تســى (مدفيتس) وهـي عبـارة عـن مـادة مكونــة مـن ســق حجـر الرخـام (كربونـات

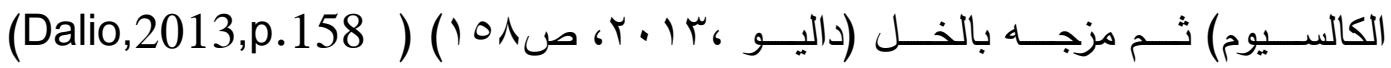

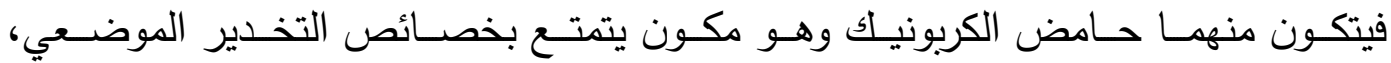

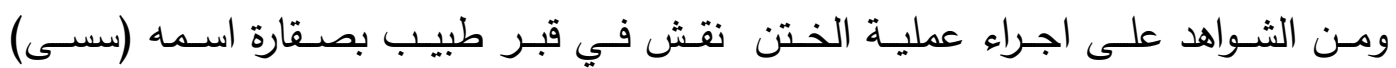

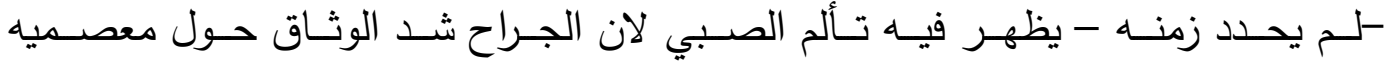

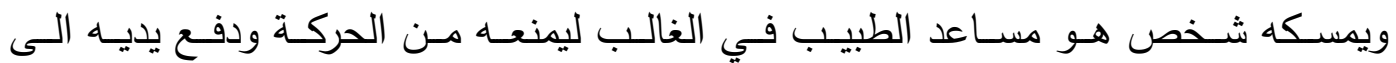




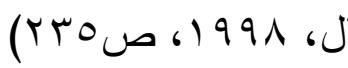

S)

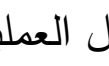

عل

الاعل

(Kamal,1998,p.235)

نخـتم بحثنـا بحقيقـة مفادهــا ان الطـب والاطبــاء المصـريين حظـوا بثـهرة واسـعة

فـي الخـارج ، فـبلاد الحيثيـين وبـلاد فـارس كانــت تحـرص علـى اسـتجلاب الـدواء واحيانـا الطبيـب المصـري في الحـالات التي يصـعب علاجهـا، كمـا ان اطبـاء الاغريـق كانوا من تلاميذ المدرسة الطبية المصرية .

الخاتمة

- على الرغم من قسوة الطبيعة التي عاش بها المصريون الا انهم وبفضل ما امتلكوه من

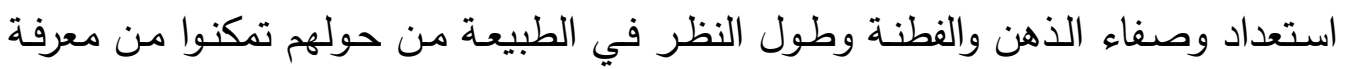

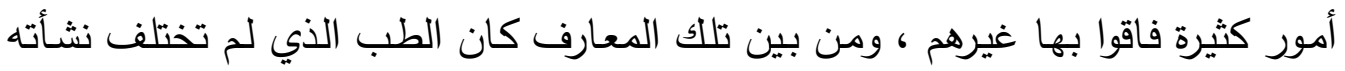

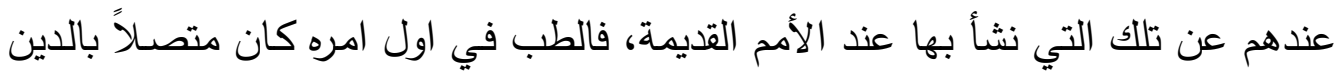

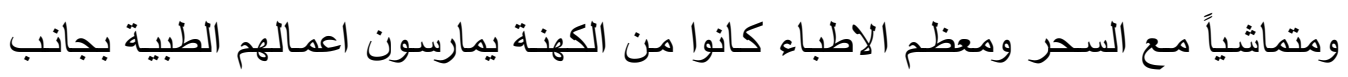

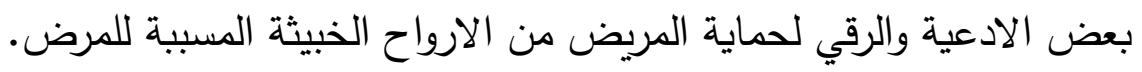

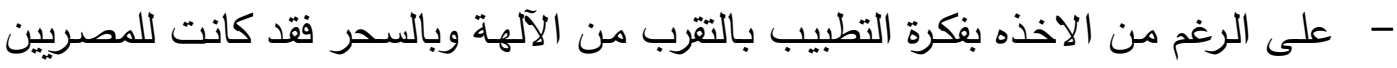

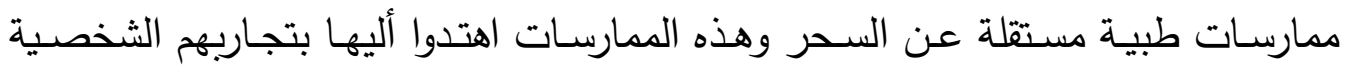

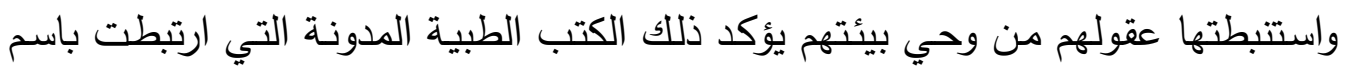
اقدم طبيب معروف الطب باسمه هو امحوتب وزير الملك زوسر ثاني من ملوك الاسرة

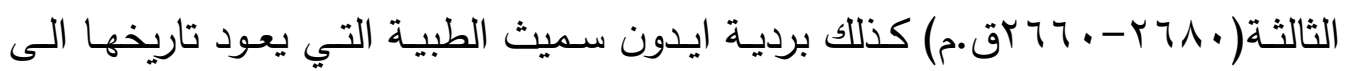

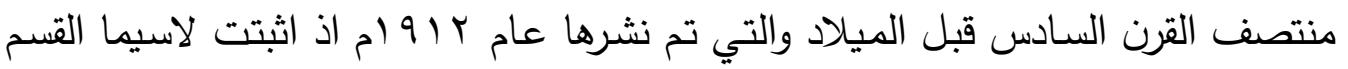

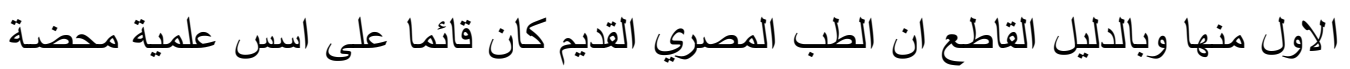
وانه لم يكن يرتكز على التعاويذ السحرية في معظم احواله.

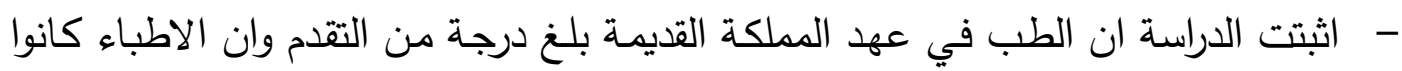
ينقسمون على فئات مختلفة من حيث العمل ومن حيث التخصص، وان معرفتهم الطبية مكنتهم من التقريق بين الطبيب المختص والمحترف غير الطبيب.

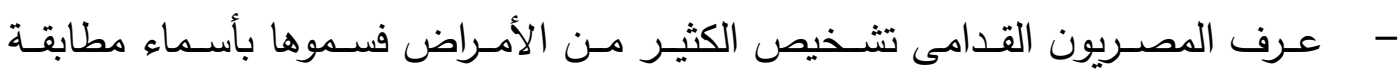

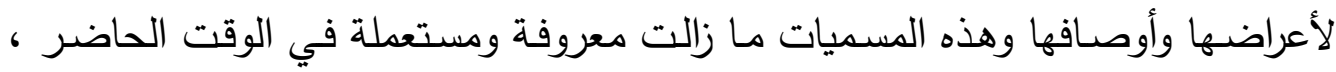

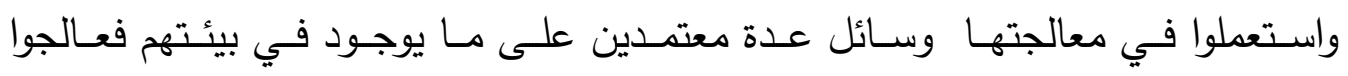

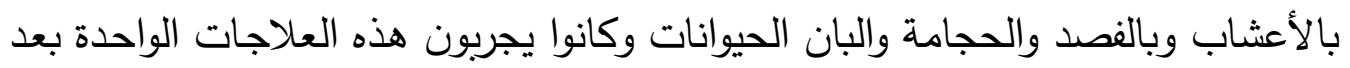

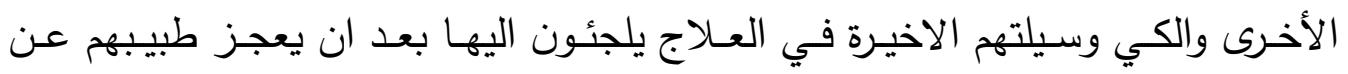
المعالجة بالوسائل التي أشرنا أليها. 
- عرفوا معالجة النزف الدموي والجروح وتعقيمها وتتظيفها من المواد العالقة بها ومن تخثر الدم ، وكانت لهم تدابير احترازية لا سيما في حالة الجروح العميقة اذ كانوا يمتنعون عن سقي المجروح بالماء ساعة جرحه وهذا ما يؤكده الأطباء اليوم ، فضـلاً عن ذلك كانت لهم معرفة بما نسميه اليوم بعمليات التجميل فعرفوا الوشم وتغطية العيوب التي تصيب بعض أعضاء الجسم بالوسائل الصناعية الى جانب ممارستهم الختان.

\section{أولا - المصادر العربية والمعربة}

- اديب، سمير . . . . . موسوعة الحضارة المصرية القديمة ـ العربي للنشر والتوزيع .القاهرة .

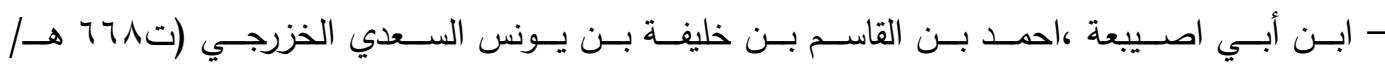

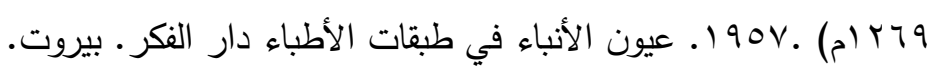

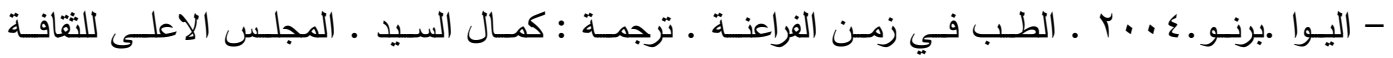
. القاهرة .

- بلاكسـلاند ، سـتبز .901 19 لمحسة عـن تـاريخ الطـب مـن السـحر السى الطب الحـديث ، ترجمـة : احمد زكي الحكيم • لجنة البيان العربي •بيروت . - جارلند ، جوزيف ـ د.ت. قصة الطب ـ ترجمة : سعيد عبده ـ دار المعارف.القاهرة

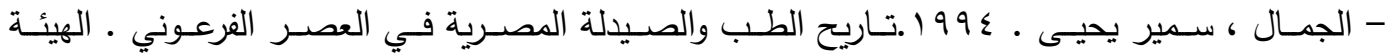
المصرية العامة للكتاب.القاهرة .

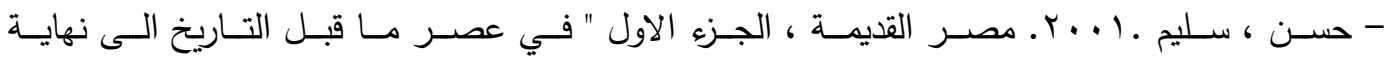

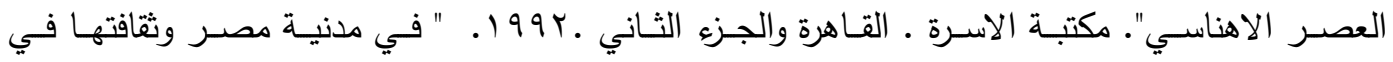

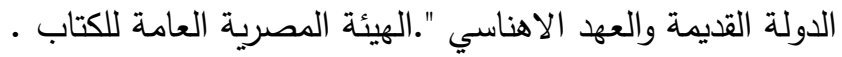

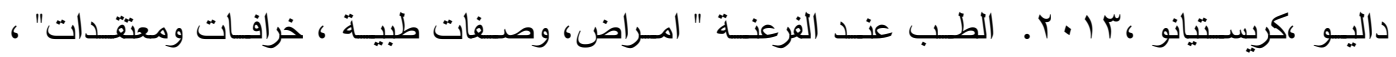

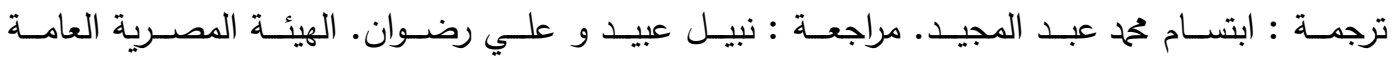
للكتاب .القاهرة.

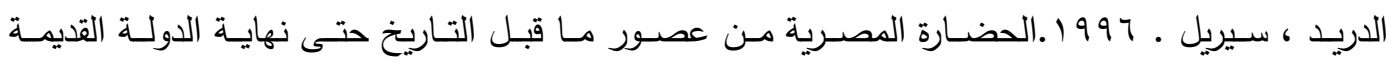
كترجمة وتحقيق مختار السويفي ـ مراجعة وتقديم : احمد قدري ـ الدار المصرية اللبنانية.القاهرة .

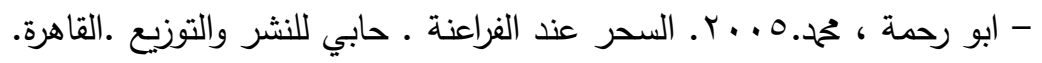

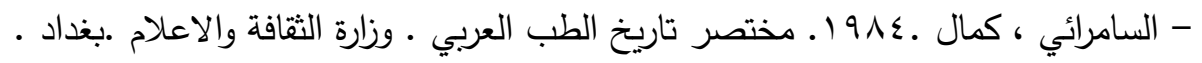
- سعد الله ، حسن .د.ت ـ من اسرار الفراعنة .مكتبة مدبولي .القاهرة .

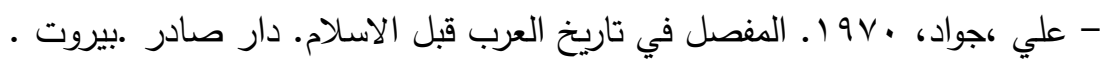

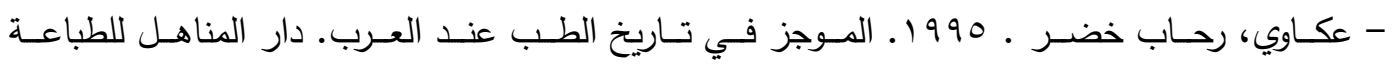
والنشر •بيروت. - غليونجي ، بول ـ 999 .طب وسحر .دار القلم ،القاهرة .

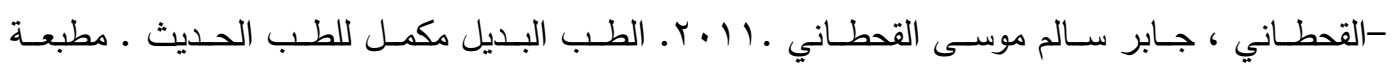

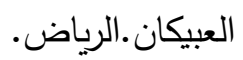


- كامل • وهيب . ب ا • r. ديودور الصقلي في .دار المعارف .القاهرة. - كمال، حسن .9919 1. الطب المصري القديم ، طب ـ ـ الهيئة العامة للكتاب .القاهرة.

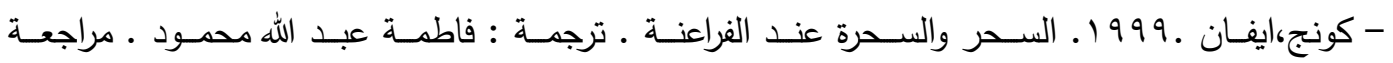
: محمود ماهر طه ـ الهيئة العامة للكتاب ،.القاهرة .

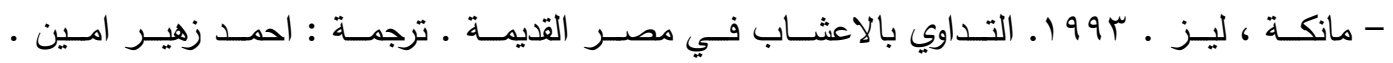

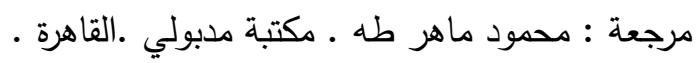
- مراد ، أمنه صبري .د.ت، لمحة عن تاريخ الطب القديم ـ مكتبة النصر الحديثة .القاهرة.

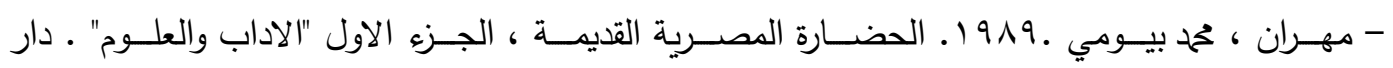
المعرفة الجامعية .القاهرة .

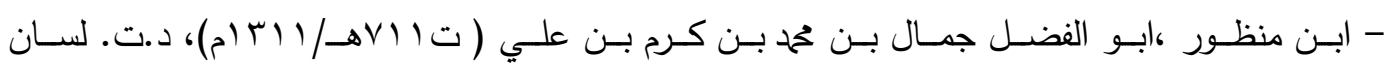

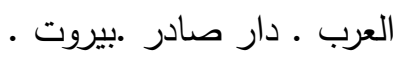

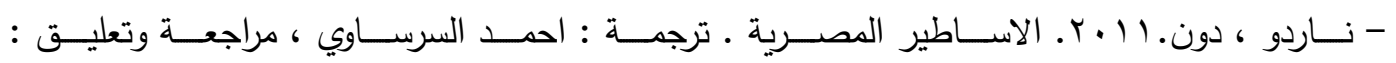

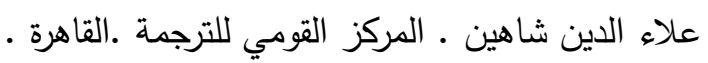

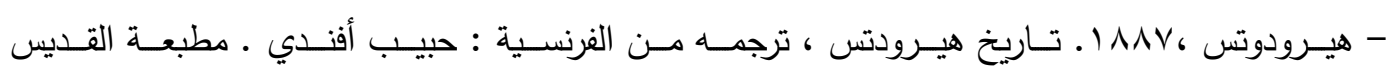

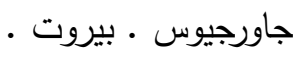
ثانيا- شبكة المعلومات الاكترونية (الانترنيت ) لبرون

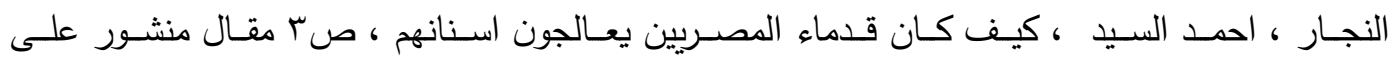

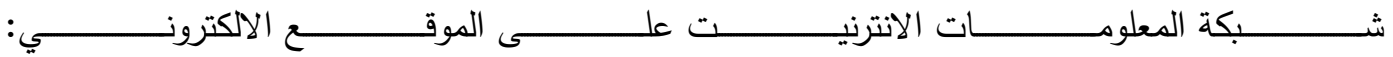
www.ahram.org.eg/NewsPrint/322911.aspx

\section{References}

First: The Arabic references and translated to Arabic

-Abu Rahma, M. (2005). Magic to Pharaohs. Cairo: Habi for publication.

-Adeeb, S. (2000). The encyclopaedia of ancient Egyptian civilisation. Cairo: Al-Arabi for publication.

-Akawi, R. K. (1995). The outline in the history of medicine to Atab. Beirut: Dar Al-Manahil for publication.

-Al-Jamal, S. Y. (1994). The history of Egyptian medicine and pharmacy in Pharaonian era. Cairo: the general Egyptian corporation of book.

-Al-Kahtani, J. (2011). The alternative medicine is a complementary of modern medicine. Al-Riyadh, Al-Ebaikan press.

-Al-Samera'I, K. (1984). The summary of Arabic medicine history. Baghdad: the Ministry of Culture and Media.

-Aldred, S. (2013). The Egyptian civilisation from the prehistory ages until the end of the ancient state. Translated by M. Al-Swaifi, reviewed and presented by A. Kadri. Cairo: Al-Dar Al-Misriah Al-Lubnania.

-Alewa, B. (2004). Medicine in Pharaohs time. Translated by K. AlSaeed. Cairo: the Supreme Council of culture.

-Ali, J. (1970). The detailed in the Arab history pre-Islam. Beirut: Dar Sader.

Blackslander, S. B. (1958). A glimpse on the history of medicine from spell to modern medicine. Tanslated by A. Z. Al-Hakeem. Beirut: AlBayan Al-Arabi committee. 
-Dalio, C. (2013). The medicine to Pharoahs "sickness, prescriptions, myths and beliefs". Translated by I. M. Abdul Majeed, reviewed by N. Ubaid and A.Radwan. Cairo: the general Egyptian corporation of book.

-Garland, j. (No Date). The story of medicine. Translated by S. Abdah. Cairo: Dar Al-Ma'aref.

- Galungi, P. (1999). Medicine and magic. Cairo: Dar Al-Kalam.

-Hassan, S. (2001). Ancient Egypt, "the age of prehistory till the end of Ahnasic era',( part one). Cairo: Al-Usra library.

(1992). Ancient Egypt, "'about the civilisation and culture of Egypt in the ancient state and Ahnasic era'" (part two). Egypt: the general Egyptian corporation of book.

-Herodotus. (1887). The history of Herodotus. Translated from French by H. Afandi. Beirut: Saint Jawargeos Press.

-Ibn Abi Usaib'a, A. (1957). The eyes of news in doctors' ranks. Beirut: Dar Al-Fikir.

-Ibn Mandhor, A. J. (No Date). The tongue of Arab. Beirut: Dar Sadir.

-Kamal, H. (1998). The ancient Egyptian medicine. (3rd Ed.). Cairo: the general corporation of book.

-Kamil, W. (2013). Dewdor the Sicilian. Cairo: Dar Al-Ma'rif.

-Kong, E. (1999). Magic and magicians to Pharaohs. Translated by F. A. Mahmood, reviewed by M. M. Taha. Cairo: the general corporation of book.

-Manka, L. (1993). Medication with herbs in ancient Egypt. Translated by A. Z. Ameen, reviewed by M. M. Taha. Cairo: Al-Madboli library.

-Mahran, M. B. (1989). The ancient Egyptian civilisation, "'literature and sciences', ( part one). Cairo: Dar Al-Ma'refa Al-Jam'ia.

-Murad, A. S. (No Date). A glimpse on the ancient medicine history. Cairo: Al-Nasir library.

-Nardo, D. (2011). The Egyptian myths. Translated by A. Al- Sersawi, reviewed and comment by A. Shahin. Cairo: the national centre of translation.

-Sa'ad Allah, H. (No Date). From the secrets of Pharaoh. Cairo: AlMadboli library.

Second: Internet resources

Al-Najar, A. How do the ancient Egyptians treat their teeth, p.3. www.ahram.org.eg/NewsPrint/322911.aspx. 


\title{
Medical practices in Egypt (the reign of the Old Kingdom
}

(3200-2270 BC) as an example)

\author{
Prof. Mahdiyah Faisal Saleh Al-Mosawi \\ University of Baghdad/ College of Education- Ibn Rushd \\ History Department \\ dr.historym.faisal@gmail.com
}

\begin{abstract}
No one can argue that medicine is one of the first knowledge which is practised by human being without knowing and by innate since the first days of history. Human's continuous endeavour to look for anything maintaining his health plays a role to know some useful remedies by chance and by repeating the experience once, and by observing and imitating animals in another time. When religion appears, he thinks that sickness is caused as a result of the anger of gods, and if prayers and sacrifices are made, the patient would be healed, i.e. medicine is interwoven with religion, that, one of the specialisations of the priest is to practise medicine, which is called the spiritual medicine. With the passage of time, the thinking of human is developed and his imagination becomes broader, so he says that sickness, especially those that are difficult to be healed, is attributed to evil spirits and devils that can break through the body. So, he becomes pleading wizards and witches for remedy, who also begin practising medicine by using some tricks and reading some phylacteries as well as carrying beads and incantations in order to frighten the evil spirits that cause sickness and, then, to go out of the body of the patient, i.e. practising what is called nowadays preventive medicine.

Despite this obvious mixing between medicine, religion, and spell, medicine in ancient Egypt never be developed than spell. The medical practices that appear since oldest times are not only independent and discrete from the magical practices, but, in the ancient kingdom era, it reaches a high level of progress and the Egyptian doctors become famous outside Egypt, and the Greek doctors are of the Egyptian medical school.
\end{abstract}

Key words: medicine, sickness, remedy, medical papyrus. 